\title{
La Corte Penal Internacional: fundamentos y características*
}

\section{Augusto Hernández Campos*}

\section{Introducción}

La creación de la Corte Penal Internacional (denominación oficial según la versión en español de su estatuto aprobado en Roma) constituye un gran avance en la historia del Derecho Internacional en general, y del Derecho Penal Internacional en especial. El desarrollo de este nuevo mecanismo de jurisdicción brindará una nueva dimensión al Derecho Internacional, con lo cual podrá afrontar nuevas y futuras bregas. Por todo ello, el Derecho Penal Internacional, y en especial su nuevo brazo la Corte Penal Internacional (CPI), continuará siendo tanto un reto como una esperanza para los estudiosos y personas interesadas que se esfuerzan en contribuir a la paz y seguridad de la humanidad a través de esta disciplina.

El objetivo de este trabajo es presentar el aporte y relevancia del nuevo instrumento jurisdiccional para sancionar las violaciones más graves a las leyes internacionales.

Para cumplir con tal finalidad, este trabajo se ha dividido en tres partes principales: en la primera parte, se revisará panorámicamente el campo de estudio del Derecho Penal Internacional; en la segunda, se revisará el aporte de los tribunales penales internacionales ad hoc; y en la tercera, con más

* A los doctores Armando Zolezzi Möller, Javier Neves Mujica y Elvira Méndez Chang con profundo reconocimiento por su constante aliento al estudio e investigación en nuestra casa de estudios

* Una versión anterior fue publicada en: Agenda Internacional (IDEI-PUCP), año V, No 11 (julio-diciembre 1998), pp. 103-128. 
detenimiento, se examinarán las características principales de este novísimo brazo judicial. En esta última parte, analizaremos la creación, y estudiaremos las distintas clases de jurisdicción de la CPI, en especial las jurisdicciones ratione materiae y ratione personae, así como el ejercicio de la jurisdicción de la Corte.

\section{Derecho Penal Internacional}

\subsection{Definición}

Es el conjunto de normas de Derecho Internacional que regula, mediante obligaciones jurídicas internacionalmente asumidas, las conductas cometidas por individuos (sea a título individual o en su condición oficial) que violen prohibiciones internacionales y para las que se prevé una sanción penal.

\subsection{Contenido}

La noción comprende las regulaciones que determinan el campo de aplicación del Derecho Penal Nacional (basándose en los principios de jurisdicción).

También, incluye al Derecho Internacional de la asistencia mutua (entre los Estados) en asuntos penales. Asimismo, comprende a las convenciones que faciliten procesos penales, la extradición, y la transferencia de prisioneros para que cumplan sus sentencias en su país de origen.

La acepción se ha extendido recientemente del Derecho Penal Internacional (DPI) sustantivo para abarcar al DPI adjetivo ${ }^{1}$, esto se debe al progreso del DPI sobretodo después de la Segunda Guerra Mundial.

Mientras que el Derecho Internacional (DI) rige las relaciones entre los Estados y se aplica a Estados y otros sujetos de DI, el DPI sugiere que existen prohibiciones legales específicas que se aplican directamente a los individuos y por violación de las cuales son hallados directamente respon-

1 El DPI sustantivo se refiere a la determinación de los crímenes internacionales, y las violaciones específicas o actos delictivos que deben ser sancionados. Por su parte, el DPI adjetivo es el de las sanciones, esto es, los compromisos colectivos y de cooperación internacional que se consideran necesarios para hacer cumplir y ejecutar las sanciones penales. 
sables. Esto significa que en cierto sentido los individuos son sujetos de DI, debido a que el individuo no puede ser protegido detrás del pretexto de la responsabilidad del Estado por sus actos².

\subsection{Dicotomía doctrinal}

Como disciplina jurídica, el Derecho Penal Internacional es el resultado de la convergencia de dos ramas fundamentales del Derecho: el Derecho Penal y el Derecho Internacional.

Señala Bassiouni que las divergencias doctrinales entre ambos sistemas jurídicos "han determinado que el DPI se configure como una "personalidad dividida $»^{3}$.

Así, por un lado, los internacionalistas tenderán a analizar al DPI en base a las obligaciones asumidas por vía convencional y las prácticas consuetudinarias internacionales de los Estados, en orden al cumplimiento de los mandatos del DPI a través de sus sistemas penales internos.

Y de otro lado, los penalistas tratarán de construir un modelo de ejecución internacional paralelo al sistema penal interno y se preocuparán de la codificación de las normas penales internacionales y su aplicación a través de un sistema internacional de justicia penal ${ }^{4}$.

\subsection{Estructura del DPI}

El contenido del Derecho Penal Internacional se subdivide en tres partes principales: la determinación de los crímenes internacionales, la responsabilidad penal individual y la aplicación de las penas. Un mecanismo

2 Vid., R. Bledsoe y B. Boczek, The International Law Dictionary. ABC-Clio, Santa Bárbara 1987, p. 75.

3 Cherif Bassiouni, Derecho Penal Internacional. Tecnos, Madrid 1984, p. 77. Bassiouni, quien fuera catedrático de la Universidad DePaul (Chicago) y secretario general de la Asociación Internacional de Derecho Penal (París), preparó un excelente proyecto de código penal internacional. Ibid.

4 Bassiouni, op. cit. Para Sauer, antiguo profesor de la Universidad de Münster (Alemania), el «Derecho Internacional significa en primer lugar la validez de normas jurídicas iguales en varios Estados; es equivalente a [...] Derecho interestatal. Un tal Derecho no existe para las leyes penales en sentido formal. Pero, realmente existe una concordancia amplia en las normas y su aplicación, así que en la existencia material del Derecho Penal Internacional no se puede dudar., Vid., Wilhelm (Guillermo) Sauer, Derecho Penal: Parte General. Bosch, Barcelona 1956, p. 30. 
complementario para la aplicación de las penas lo constituye la figura de la extradición.

\section{Figura 1: Lugar de la CPI en el Derecho Penal Internacional}

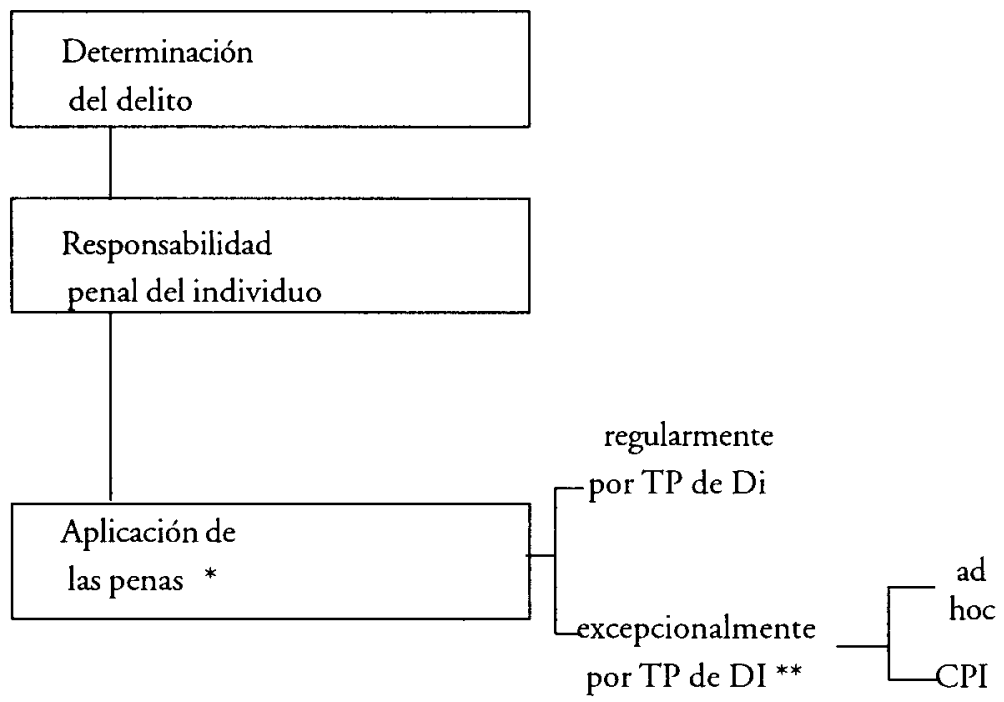

Nota: En el Derecho Internacional, las penas han sido determinadas y aplicadas regularmente por cortes o Tribunales Penales (TP) de Derecho interno (Di), y sólo a título excepcional por Tribunales Penales Internacionales, i.e., los tribunales ad hoc.

* La extradición sirve como un mecanismo auxiliar muy relevante, mas no constituyen un elemento sine qua non para poder llegar a aplicar las penas.

** Hasta ahora los tribunales internacionales han sido para casos especiales. La Corte Penal Internacional será permanente.

\subsubsection{Los crímenes internacionales}

La labor del Derecho Internacional la constituye en este campo la determinación y tipificación de los crímenes o delitos contra el derecho internacional (delicta iuris gentium), así como su clasificación y tipología. Los delitos internacionales conforman el DPI sustantivo. Constituiría objeto de estudio de la Criminología Internacional ${ }^{5}$.

5 Para interesantes análisis sobre los crímenes internacionales, vid., Beatriz Ramacciotti, "El terrorismo como crimen internacional", Agenda Internacional I, 2 (julio-diciembre de 1994), pp. 139-171; Roberto Ago, "Le délit internacional", Recueil des Cours de l'Academie de Droit International (RCADI), t. II (1939); Stefan Glaser, "Culpabilité en Droit 
Esta parte, formada por los delitos que el Derecho Internacional determina como tales, representaba el contenido (en conjunto con la responsabilidad penal individual) del Derecho Penal Internacional en el Derecho clásico.

\subsubsection{Definición}

Se puede considerar como crimen internacional a toda conducta que constituye una violación grave de los principios de ius cogens ${ }^{6}$ del Derecho Internacional.

\subsubsection{Las clases de crímenes internacionales: tipología}

La doctrina clasifica los crímenes internacionales en dos categorías: los crímenes internacionales en sentido estricto y los crímenes internacionales en sentido amplio.

Triffterer divide los crímenes internacionales en sentido estricto y aquellos en sentido amplio ${ }^{7}$. Jeschek mantiene esta división entre crímenes contra el Derecho Internacional y crímenes internacionales en sentido amplio ${ }^{8}$. Estas opiniones son representativas del sector mayoritario de la doctrina al respecto. Pastor Ridruejo suscribe la diferencia de los actos ilícitos entre crímenes y delitos. ${ }^{?}$

International Penal", RCADI, t. 99 (1960), pp. 467-592; Alicia Gil Gil, El genocidio y otros crimenes internacionales: Centro Francisco Tomás y Valiente, Valencia 1999.

6 Como la protección de los Derechos Humanos, la protección de las normas humanitarias (y del Derecho de los Conflictos Armados), y el principio de prohibición del uso de la fuerza.

7 O. Triffterer, "Present Situation, Vision and Future Perspectives», en Eser/Lagodny (eds.), Principles and Procedures for a New Transnational Law (Friburgo de Brisgovia: Albert Verlag, 1991), pp. 337 et seq., cit. por Gil, ibid., p. 44.

8 Hans-Heinrich Jescheck, «International Crimes», en: R. Bernhardt (ed.), Encyclopedia of Public International Law, vol. II (Amsterdam: Elsevier, 1992), pp. 11 19-1123.

9 A juicio de Pastor Ridruejo, dentro del acto ilícito internacional existen dos categorías, crimen y delito internacionales, según la naturaleza de la obligación internacional quebrantada. Pastor Ridruejo los diferencia: "Si la obligación vulnerada es "tan esencial para la salvaguardia de intereses fundamentales de la comunidad internacional que su violación esté reconocida como crimen por esa comunidad en su conjunto" (p. 2 del Art. $19^{\circ} \mathrm{del}$ Proyecto de la Comisión de Derecho Internacional) se trata de la figura del crimen internacional. En los casos restantes la violación no pasa de constituir un delito internacional (p. 4 del mismo artículo)». Vid., J.A. Pastor Ridruejo, Curso de Derecho Internacional Público (Madrid: Tecnos, 1986), p. 489. 
(A). Crímenes internacionales en sentido estricto

Los crímenes en sentido estricto amenazan normas fundamentales (ius cogens) de Derecho Internacional y causa una responsabilidad basada directamente en el DI (crímenes contra la paz y seguridad de la humanidad, ponen en peligro la paz internacional, también llamados crímenes o delitos internacionales).

Los crímenes strictu sensu están integrados por la tipología de Nüremberg. En el derecho moderno, surgió en base a los principios de Nüremberg de 1946 la tipología de los crímenes internacionales (en sentido estricto): crímenes contra la paz, crímenes de guerra (existente ya en el Derecho clásico y sancionables conforme al DI consuetudinario), y crímenes contra la humanidad (incluyendo genocidio ${ }^{10}$ ).

\section{Tabla 1: Terminología y clases de los delitos o crímenes internacionales (delicta iuris gentium)}

\begin{tabular}{|c|c|}
\hline términos & crímenes \\
\hline $\begin{array}{l}\text {-delitos o crímenes } \\
\text { internacionales strictu sensu } \\
\text {-delitos o crímenes contra la paz } \\
\text { y seguridad de la humanidad } \\
\text {-Tipología de Nüremberg } \\
\text {-delitos internacionales } \\
\text {-crímenes contra el DI }\end{array}$ & $\begin{array}{l}\text { incluidos } \\
\text { 1. crímenes contra la paz } \\
\text { 2. crímenes de guerra } \\
\text { 3. crímenes contra la } \\
\text { humanidad }\end{array}$ \\
\hline $\begin{array}{l}\text {-delitos o crímenes } \\
\text { internacionales latu sensu } \\
\text {-delitos transnacionales o } \\
\text { transfronterizos } \\
\text {-crímenes internacionales en } \\
\text { sentido amplio }\end{array}$ & $\begin{array}{l}\text { Piratería, tráfico de } \\
\text { esclavos, narcotráfico, etc. }\end{array}$ \\
\hline
\end{tabular}

Nota: Los crímenes internacionales pueden dividirse entre aquellos en sentido estricto o crímenes contra el DI (grado máximo), y aquellos en sentido amplio (grado general).

10 Convención sobre la Prevención y Castigo del Crimen de Genocidio de 1948; Convención Internacional sobre la Supresión y Castigo del Crimen del Apartheid de 1973. Sobre un estudio inicial de los crímenes contra la humanidad, Jean Graven, «Les crimes contre l'humanitè, RCADI, t. 76-I (1950), pp. 433-607. 
(B). Crímenes internacionales en sentido amplio

Los crímenes en sentido amplio son sancionables en el Derecho interno (crímenes de Derecho interno), pero a su vez son de interés mundial pues todos los Estados convienen en su supresión. También, se les ha llamado delitos transnacionales ${ }^{11}$.

Estos crímenes se dividen entre:

a) Aquellos reconocidos por DI consuetudinario en el DI clásico, por ejemplo, piratería.

b) Aquellos ya determinados por la costumbre clásica pero que han sido codificados por el DI moderno, como el tráfico de esclavos, tráfico de mujeres y de niños.

c) A estos delitos, el DI moderno ha añadido otros contemporáneos, e.g. terrorismo internacional o narcotráfico.

Así, los crímenes latu sensu incluyen los contemplados en el Derecho Internacional clásico como el delito de piratería (marítima ${ }^{12}$ y aérea ${ }^{13}$ ), las violaciones de las leyes y costumbres de la guerra, y el tráfico de esclavos ${ }^{14}$ (más el tráfico de mujeres y niños) ${ }^{15}$.

También, se añadirían otros crímenes específicos modernos como falsificación de moneda ${ }^{16}$, tráfico ilícito de drogas ${ }^{17}$ ( $\mathrm{y}$ de armas y migrantes), $y$ terrorismo internacional ${ }^{18}$, delitos contra personas internacionalmente

11 A. Gil Gil, Derecho penal internacional (Madrid: Tecnos, 1999), p. 43. Sobre crímenes en el Derecho Internacional clásico, vid., Maurice Bourquin, "Crimes et délits contre la sureté de l'Etats étrangers", RCADI, T. 16-I (1972), pp. 121-245.

12 Convención sobre Derecho del Mar de 1982 (arts. 101º y 105\%).

13 Convención para la Supresión de Captura Ilegal de Aviones de La Haya de 1970. También, la Convención para la Supresión de Actos Ilegales contra la Seguridad de Aviación Civil de 1971 . Al respecto puede consultarse, Harry Awner, La llamada "piratería aérea» en el derecho internacional (Santiago: Jurídica, 1988).

14 Convención para la Supresión del Tráfico de Personas y de la Explotación de la Prostitución y Otros de 1949.

15 Protocolo de 1947 para enmendar la Convención para la represión de la trata de mujeres y niños.

16 Convención internacional para la Represión de la Falsificación de Moneda de Ginebra de 1929.

17 La Convención Unificada sobre Drogas de 1961, modificado por el Protocolo de 1972.

18 Convención para la prevención y represión del terrorismo de 1937. Puede consultarse, Gilbert Guillaume, "Terrorisme et droit international", Recueil des Cours de l'Academie de Droit International, t. 215-III (1989), pp. 287-416. 
protegidas ${ }^{19}$. Asimismo, pesca excesiva, contaminación marina con petróleo y otros contaminantes, daños a cables submarinos, y toma de rehenes $^{20}$. Otros tratadistas incluyen tráfico internacional de publicaciones obscenas ${ }^{21}$, violación de reglas protectoras de propiedad cultural en tiempo de guerra (aunque podríamos incluirla dentro de crímenes de guerra) ${ }^{22}$, transmisiones prohibidas radiales de fuera del territorio soberano (radiodifusión pirata), y la corrupción de funcionarios públicos ${ }^{23}$.

Los demás tipos de quebrantamientos de las normas internacionales por el individuo podríanse considerar como infracciones internacionales ${ }^{24}$.

1.4.1.3. Determinación y tipificación: los elementos del crimen internacional

Según algunos estudiosos, los actos considerados como crímenes internacionales deben presentar algunos elementos constitutivos característicos. Los elementos para tipificar y determinar los crímenes internacionales son cinco principales ${ }^{25}$ :

- elemento internacional (el acto afecta la seguridad internacional)

- elementos objetivo y subjetivo (consiste en la violación de una norma de ius cogens y en la presencia de un sujeto al cual se le imputa tal acto)

- acción masiva (un acto ilícito muy grave que amenaza la seguridad internacional o la humanidad)

- gravedad (significa que afecta los fundamentos mismos de la humanidad deducido del carácter del acto, la amplitud de sus efectos o el objetivo del autor)

19 La Convención sobre Prevención y Castigo de los Crímenes contra Personas bajo Protección del DI, Incluyendo Agentes Diplomáticos de 1973.

20 H.H. Jescheck, "International Crimes», en: R. Bernhardt (ed.), Encyclopedia of Public International Law, vol. II (Amsterdam: Elsevier, 1992), pp. 1120-1122.

21 Arreglo relativo a la represión de la circulación de publicaciones obscenas modificado por el Protocolo de 1949.

22 Convención de La Haya para la protección de bienes culturales en tiempo de conflicto armado de 1954.

23 H.H. Jescheck, ibid.

24 Por ejemplo, si un soldado prisionero, que está obligado en virtud de las Convenciones de Ginebra a dar sus datos básicos (nombre, rango y número de serie), se niega a darlos. Obviamente no comete un crimen, más bien sería una infracción.

25 Sobre la tipificación del crimen internacional puede consultarse, Ramacciotti, $o p$. cit., pp. 143-145. También, Bassiouni, op. cit.. 
- calificación internacional (basta que el crimen esté calificado como tal mediante tratado u otra fuente del DI)

\subsubsection{Responsabilidad penal internacional del individuo}

Los delicta iuris gentium («crímenes contra el Derecho Internacional») generan específicamente la responsabilidad penal del individuo en el Derecho Internacional. Como se sabe, la responsabilidad internacional es una de las consecuencias del acto internacionalmente ilícito.

En su sentencia en el caso de Fábrica Chorzow de 1928, la Corte Permanente de Justicia Internacional (CPJI) sostuvo que:

«Es un principio de Derecho Internacional, e incluso un principio general de Derecho, que cualquier incumplimiento de un compromiso implica la obligación de efectuar una reparación". ${ }^{26}$

En el caso de la responsabilidad penal del individuo su consecuencia jurídica es la imposición de la pena (mediante procedimiento), aunque puede incluir la reparación (similarmente al Estado ${ }^{27}$ ).

\section{Diferencia con la responsabilidad del Estado}

El concepto de responsabilidad penal del individuo por crímenes internacionales debe distinguirse de la responsabilidad de los Estados por infracciones internacionales. Una infracción internacional es un acto ilícito efectuado por un sujeto de DI que quebranta los derechos internacionales de otro sujeto y dan lugar a la obligación de efectuar una reparación (al cual pertenece el individuo que cometió el acto).

Empero, una infracción internacional de un Estado puede constituir al mismo tiempo un crimen contra el Derecho Internacional, como los crímenes de guerra (algunos sectores de la doctrina denominan a los crímenes internacionales de los Estados como «crímenes de Estado» ${ }^{28}$ ).

26 Sentencia en el caso de la Fábrica de Chorzow (13 de setiembre de 1928) visto por la CPJI (Alemania vs. Polonia). CPJI, Serie A, no. 17, p. 29.

27 Así lo contempla, p.e., el estatuto de la Corte Penal Internacional de 1998. Sobre la responsabilidad del individuo, vid., Lyals S. Sunga, Individual responsibility in international law for serious human rights violations (Holanda: Nijhoff, 1992).

28 Mariño Menéndez propone el término «crimen de Estadom, vid., F.M. Mariño 
Ambos tipos de responsabilidad del individuo y del Estado por crímenes de guerra pueden coexistir simultáneamente. Un caso reciente es el ocurrido durante la Guerra de la Antigua Yugoslavia cuando serbios perpetraron crímenes de guerra, en el marco de la limpieza étnica, coexistía la responsabilidad de individuos (e.g., Karadzic y Mladic fueron acusados por responsabilidad directa por el Tribunal de la Antigua Yugoslavia) y la del Estado (Bosnia demandó a Serbia-Montenegro ante la CIJ en 1993 por incumplimiento de la Convención contra el Genocidio, la corte condenó a Serbia por dicho incumplimiento e instó a que actúe conforme a la citada Convención).

\section{Responsabilidad penal de las personas jurídicas}

El Derecho Penal Internacional implica la responsabilidad penal individual, la única posible en Derecho Penal, pues las personas jurídicas carecen de capacidad de cometer un crimen por acción u omisión en el sentido del Derecho Penal, con lo que no pueden realizar siquiera el primer elemento del delito en sentido penal y por lo tanto no se le podrá imponer penas conforme a dicha rama del Derecho ${ }^{29}$. Esta situación se contrasta con el proceso de Nüremberg que permitió la responsabilidad de organizaciones calificadas como criminales.

\subsubsection{Aplicación de las penas}

Debido a que los crímenes internacionales se configuran como una infracción universal, todo Estado en donde se halle detenido un individuo responsable de estos actos tiene el deber de: conceder su extradición (para castigarlo) o de castigarlo (principio aut dedere aut punire enunciado por Hugo Grocio $^{30}$ ). Esto constituye la universalidad de la jurisdicción penal de los Estados (jurisdicción universal) en esta materia delictiva ${ }^{31}$.

Menéndez, Derecho Internacional Público, cit por A. Gil Gil, Derecho Penal Internacional (Madrid: Tecnos, 1999), pp. 42-43, n. 57.

29 La mayoría de la doctrina rechaza la responsabilidad de las personas jurídicas, aunque es aceptada por el derecho anglosajón y ha hallado acogida en la legislación francesa y noruega, pero incluso dichos textos excluyen expresamente la responsabilidad penal del Estado. Vid., Gil, op. cit., pp. 41-42.

30 Vid., C. Bassiouni, Derecho Penal Internacional (Madrid: Tecnos, 1984), p. 83.

31 La jurisdicción universal de los Estados representa un mecanismo esencial ante la 
Esto es a causa que «no existe una autoridad legislativa [mundial] y la principal fuente es la propia voluntad de los Estados, para que surja una norma de Derecho penal internacional los Estados tienen que reconocerla como obligatorian ${ }^{32}$.

Aquí la determinación y la aplicación de las penas estaba a cargo de procedimiento de jurisdicción de los Estados (mediante tribunales o procedimientos de Derecho interno), y excepcionalmente a cargo de procedimientos internacionales mediante tribunales internacionales regulados por el DI.

\section{(A) MEDIANTE JURISDICCIONES NACIONALES}

Generalmente, el Derecho Internacional se limita a determinar los delitos y la consiguiente responsabilidad penal individual por tales violaciones del Derecho Internacional.

En cuanto a las penas, éstas, por regla, son determinadas e impuestas a los individuos, no por un procedimiento internacional determinado, sino mediante procesos en tribunales penales de Derecho interno (u otro procedimiento debido al ejercicio de la jurisdicción nacional del Estado que los tiene en custodia ${ }^{33}$ ).

Correspondería su estudio a la Justicia Penal Comparada (o Derecho Procesal Penal Comparado). Según Oda, «un análisis adecuado de estos casos demostraría, por consiguiente, que son meros ejemplos de una jurisdicción excepcionalmente amplia de los Estados»" ${ }^{34}$.

En la aplicación de un procedimiento penal, la jurisdicción de los Estados suelen recurrir a diversos principios:

- El principio de territorialidad: tiene jurisdicción el Estado en cuyo territorio se produce el crimen.

- El principio de nacionalidad (o de personalidad activa o de la nacionalidad del infractor): ejerce jurisdicción el Estado contra nacionales que hayan cometido serios delitos contra sus intereses (violando su

inexistencia de un sistema jurisdiccional penal internacional permanente y efectivo en la actualidad.

32 Gil, ibid., p. 52.

33 Vid., Shigeru Oda, "El individuo en el derecho internacional», en Max Sorensen

(ed.) Manual de Derecho Internacional Público (México: FCE, 1985), p. 492.

34 Oda, ibid. 
orden jurídico) y estén localizados en el extranjero (p.e. caso Laval ${ }^{35}$ ), sin el prerrequisito de lex loci.

- El principio de protección (o del interés protegido): un Estado ejerce jurisdicción contra individuos extranjeros que hayan cometido en el exterior actos contra la seguridad e interés de dicho Estado, para la protección del Estado, como si se hubiera cometido dentro del mismo (p.e. falsificación de moneda en el exterior).

- El principio de universalidad (jurisdicción universal): es la aplicación universal de la jurisdicción de un Estado contra individuos nacionales o extranjeros que hayan cometido, aún en el exterior, los delicta iuris gentium. (p.e. caso Eichmann ${ }^{36}$ ).

- El principio de personalidad pasiva (o de la nacionalidad de la víctima): un Estado puede ejercer jurisdicción contra extranjeros que hayan cometido, en el exterior, actos contra individuos nacionales de un Estado (e.g. asesinato de turistas nacionales de ese Estado en el exterior; terrorismo, crímenes de guerra o violaciones de DI perpetrados contra sus nacionales). Este principio es el más controvertido de todos y es raramente invocado sin el prerrequisito de lex loci. ${ }^{37}$

\section{(B). MEDIANTE JURISDICCIONES INTERNACIONALES}

Excepcionalmente (a partir del Derecho Internacional moderno), en algunos casos el individuo responsable ha sido penado a través de tribunales penales internacionales ${ }^{38}$, después de la Segunda Guerra Mundial (con

35 Pierre Laval, acusado con colaboracionismo con Alemania y de dirigir un gobierno títere francés, había quebrantado el orden jurídico de Francia, empero huyó a España al finalizar la guerra. Francia ejercía jurisdicción sobre Laval, pero debía solicitar la extradición a Madrid para aplicar sus leyes respectivas.

36 Israel ejerció jurisdicción contra Eichmann por crímenes de guerra y crímenes contra la humanidad, pese a la falta de vínculo entre los crímenes e Israel. Esto era debido a que los crímenes se cometieron en otro lugar (Europa), las víctimas no eran nacionales de Israel, Eichmann tampoco lo era, y antes del nacimiento de Israel como Estado (en 1948).

37 Ohler añade otros dos principios de jurisdicción: el de administración representativa de la justicia penal (basado en el principio aut dedere aut punire) y el moderno de división de jurisdicción (o de responsabilidades, hace depender la aplicación de la ley penal nacional del lugar de la comisión del delito, de la nacionalidad del infractor y del interés protegido). Cf., Dietrich Ohler, "Criminal Law, International", en: R. Bernhardt (ed.), Encyclopedia of Public International Law I (1992), pp. 878-879.

38 En los tribunales ad hoc y por el tribunal permanente (la CPI). Estos casos están vinculados, principalmente, con el mantenimiento de la paz internacional. 
los Tribunales de Nüremberg y de Tokio) y más modernamente después del fin de la Guerra Fría (con los tribunales para la Antigua Yugoslavia y de Ruanda) y ad portas del Siglo XXI con la Corte Penal Internacional (originando así el Derecho Procesal Penal Internacional, como rama especializada del DPI).

Estos casos de tribunales internacionales tienen relación con la violación grave de los intereses fundamentales de la humanidad como la paz y seguridad internacionales y los derechos humanos.

\subsubsection{La extradición o transferencia}

La extradición también se encuentra dentro del DPI ${ }^{39}$, como elemento complementario para la aplicación de las penas, observándose que en muchos tratados bilaterales o regionales ${ }^{40}$ ya se ha permitido la extradición de nacionales a su Estado respectivo.

La extradición permite que un Estado llegue a tener en custodia a individuos, nacionales o extranjeros, localizados en el exterior y acusados de violar sus normas, para así poder aplicar su jurisdicción en cuanto a su procesamiento o imposición de penas (p.e., casos Laval, Eichmann, Priebke).

La "entrega" o "transferencia» es una expresión utilizada para abarcar casos en donde un acusado es puesto a disposición de un tribunal internacional para juzgarlo ${ }^{41}$. Esta noción sirve para diferenciarla del concepto clásico de «extradición» u otras formas de transferencia de personas entre dos Estados.

39 Vid., Marco Monroy Cabra, Manual de Derecho Internacional Público (Bogotá: Temis, 1986), pp. 8-9. Para un marco introductorio a la extradición, vid., Luis A. Bramont Arias, Derecho Penal: Parte General (Lima: s.e., 1978), pp. 211-223; F. O'Malley Planells, La extradición y su estudio como figura del Derecho Penal Internacional (Bogotá: Pontificia Universidad Javeriana, 1984). También, a título introductorio, Michael Akehurst, Introducción al derecho internacional (Madrid: Alianza Editorial, 1979): 142-146.

40 Por ejemplo, la Convención Europea de Extradición de 1957.

41 Esta disposición es contemplada por los tribunales de la Antigua Yugoslavia y de Ruanda, y ahora por la CPI. No necesitó recurrirse a la transferencia de individuos a los tribunales de Nüremberg y de Tokio, pues las fuerzas aliadas arrestaron a todos los acusados en Alemania y Japón, excepto a Bormann quien fue juzgado in absentia. En jurisdicción concurrente, la jurisdicción primaria es la de los tribunales ad hoc. 
Esta figura es complementaria a la aplicación de las penas pero no tienen condición sine qua non. La sanción de los individuos puede realizarse incluso prescindiendo de la extradición o entrega.

Así, pudo Israel, en base al principio de jurisdicción universal, justificar el juicio de Adolf Eichmann (por crímenes contra la humanidad), pero no su captura furtiva (pues fue secuestrado y no extraditado, violando la soberanía de Argentina). En los procesos de Nüremberg y de Tokio no se recurrió a solicitar la entrega de individuos pues fueron todos arrestados por las fuerzas aliadas.

\subsection{Codificacion del Derecho Penal Internacional}

El Derecho Internacional se está transformando debido al proceso de positivación; en muchas áreas ha pasado de consuetudinario a convencional como en el Derecho Diplomático (Convención de Viena sobre Relaciones Diplomáticas de 1961), Derecho del Mar (Convención de Derecho del Mar de 1982), o el Derecho de los Tratados (Convención de Viena sobre Derecho de los Tratados de 1969). En el Derecho Penal Internacional, no ha habido un avance comparable representado por un convenio o código general sobre esta disciplina juridica, es por tanto una de las áreas relativamente no escritas del Derecho Internacional.

Intentos para formalizar un código penal internacional (que trate con el campo del DPI) y para crear una corte penal internacional (que maneje los casos de violación del DI) no han sido exitosos y datan al menos de las propuestas la "Peace Society" (asociación de juristas en EEUU) que trataron de elaborar en 1872 un Código Penal Internacional ${ }^{42}$.

En la década de 1920, la Unión Interparlamentaria (cuyos esfuerzos datan desde 1875) preparó un código penal internacional. En esta época, el liderazgo en la investigación sobre las cuestiones relativas a un código penal internacional y una corte permanente fue asumido por la Asociación Internacional de Derecho Penal, la Asociación Jurídica Internacional y la Unión Interparlamentaria ${ }^{43}$.

Tras la creación de la ONU en 1945, el tema del DPI y su codificación había sido afrontado con resultados diversos como la Convención de Genocidio de 1948 y el Proyecto de Código de Crímenes contra la Paz y

42 C. Bassiouni, Derecho Penal Internacional (Madrid: Tecnos, 1984), p. 13.

43 Ibid., p. 14. 
Seguridad de la Humanidad de 1954. Recordemos que en 1947, la Asamblea General de la ONU ${ }^{44}$ ya había encomendado a la CDI la formulación de un primer proyecto de Código de crímenes contra la paz y seguridad de la humanidad, elaborado en 1951, así como un primer proyecto de estatuto de Corte Penal Internacional también terminado en 1951.

Sin embargo, no hubo un progreso sustancial hasta la década de 1990 (al menos con respecto a la corte la codificación ha avanzado con la formulación del estatuto).

Desde entonces, nos recuerda Tomuschat, se estancó el desarrollo del DPI, durante el debate sobre los aspectos sustantivos y procesales de la materia, fue que la definición de agresión tenía que superarse antes que se realizara ulteriores avances; pues, el crimen de agresión era medular en el conjunto de crímenes contra la paz y seguridad de la humanidad ${ }^{45}$.

Un código penal internacional, según proyectos del mismo, sería aplicado jurisdiccionalmente a través de dos formas:

(a) Directamente por un TPI (apoyado provisoria y complementariamente por tribunales penales internacionales ad hoc).

(b) O indirectamente por sistemas internos de justicia penal (TP nacionales).

\section{Los Tribunales Penales Internacionales}

\subsection{Primeros Planteamientos}

Los intentos de creación de mecanismos de jurisdicción penal internacional datan de inicios del siglo XX.

Después de la Primera Guerra Mundial, numerosos juristas impulsaron una auténtica campaña en favor de la adopción de un código penal internacional y de la creación de una corte penal internacional.

En la década de 1920, la ADI (Asociación de Derecho Internacional) propuso el establecimiento de una cámara separada de la CPJI (Corte Permanente de Justicia Internacional) para confrontar sólo casos pena- 
les ${ }^{46}$, y la Unión Interparlamentaria el mencionado proyecto de un Código Penal Internacional ${ }^{47}$.

Desde entonces se han acumulado los proyectos más diversos de código y de tribunal, propuestos desde instancias académicas, por ejemplo, la ASIL planteó su interés al respecto en $1950^{48}$, o intergubernamentales, como la CDI (Comisión de Derecho Internacional de la ONU) recomendó repetidamente la creación de una Corte Penal Internacional ${ }^{49}$.

\section{2. los tribunales ad hoc}

\subsubsection{El Tratado de Versalles}

Aparte de las propuestas académicas, hemos podido ver asimismo la plasmación de algunos experimentos prácticos de creación de jurisdicciones penales internacionales, siendo el primero el intentado después de la Primera Guerra Mundial.

Así, se estableció en el Tratado de Paz de Versalles (28 de junio de 1919) la Parte VII «Sanciones» (arts. 227 ${ }^{\circ}-230^{\circ}$ ) para sancionar la responsabilidad penal de individuos por cometer crímenes. Simultáneamente, la Parte VIII "Reparaciones» (arts. 231 ${ }^{\circ}-247^{\circ}$ ) trataba con la reparación que debía efectuar Alemania por incurrir en responsabilidad internacional por cometer actos ilícitos ${ }^{50}$.

46 En 1926, el I Congreso Internacional de Derecho Penal (Bruselas) adoptó una resolución favorable a la creación de una CPI.

47 Robert Bledsoe y Boleslaw Boczek, The International Law Dictionary (OxfordSanta Bárbara: ABC-Clio, 1987), p. 75.

48 ASIL, American Society of International Law, Sociedad Estadounidense de Derecho Internacional.

49 R. Bledsoe y B. Boczek, ibid.

50 Esta era una figura diferente de la tradicional indemnización (o compensación) de guerra que imponía el Estado vencedor al vencido sólo porque había ganado la guerra y no porque el vencido sostuviera una guerra ilícita, pues en el DI clásico la guerra no estaba prohibida ni ilegalizada. Las reparaciones impuestas a Alemania fueron porque, a juicio de los aliados, Berlín había llevado a cabo una guerra ilegal en 1914 (responsabilidad del Estado por actos ilícitos cuya consecuencia es la obligación de efectuar una reparación). Sobre las nociones de indemnización de guerra y reparaciones, vid., C. Rousseau, Derecho Internacional Público (Barcelona: Ariel, 1966), pp. 585-586. 


\subsubsection{Crimen contra la paz}

El Art. $227^{\circ}$ del Tratado de Paz de Versalles de 1919 previó la creación de un tribunal penal interaliado (i.e., internacional) para juzgar al kaiser Guillermo II de Alemania por crimen contra la paz, especialmente: «por ofensa suprema contra la moral internacional y a la autoridad sagrada de los tratados" ${ }^{51}$. Empero, como nos recuerda Röling "el proceso nunca tuvo lugar a causa que Holanda [en donde se hallaba exiliado el ex-kaiser] se negó a extraditar ${ }^{52}$ al antiguo emperador $"$ s3.

Al respecto, señala acertadamente Tomuschat:

"[...] en 1919 era extremadamente incierto de qué podía haber sido acusado el kaiser bajo el Derecho Penal. No existía proscripción de las guerras de agresión [...] y [...] los historiadores no se han puesto de acuerdo quién fue finalmente el responsable del estallido de la Primera Guerra Mundial. Mientras que el quebrantamiento de un tratado es un acto ilícito bajo el DI en el sentido clásico, [tal acto] todavía no se había convertido en una ofensa criminal por cuya consecuencia debían abrirse procesos penales contra los líderes responsables." ${ }^{54}$

Si bien este caso puede ser citado como antecedente, su fundamento jurídico no es relevante como precedente para la responsabilidad penal individual por una guerra de agresión o crimen contra la paz porque tal clase de responsabilidad no existía en 1914 conforme al Derecho Internacional vigente.

51 Hacía referencia a la violación de los tratados de 1831 (Tratado de Londres en donde la neutralidad belga era garantizada por Austria, Rusia, Inglaterra y Prusia) y 1839 que establecían la neutralidad permanente de Bélgica. Quizá también aludía al tratado de 1867 que establecía la neutralidad de Luxemburgo.

52 En dos ocasiones el gobierno holandés se negó (notas del 24 de enero y del 6 de marzo de 1920). Holanda se negó a conceder la extradición en base a que el delito del que se le acusaba era un "delito político" y, por tanto, excluido de la extradición, por tanto aplicando la tradicional extensión del Derecho de Asilo a esta clase de delincuentes. Vid., Charles Rousseau, Derecho Internacional Público (Barcelona: Ariel, 1966), p. 576.

53 Bert V.A. Röling, “Crimes against peace», en: R. Bernhardt (ed.), Encyclopedia of Public International Law, vol. I (1992), pp. 871-875.

54 Vid., Christian Tomuschat, «From Nïremberg to The Hague», Law and State 53-54 (1996): 115 . 


\subsubsection{Crímenes de guerra}

Por otra parte, el Tratado de Versalles establecía, en relación con los crímenes de guerra, las siguientes medidas en los arts. $228^{\circ}-230^{\circ 55}$.

\section{Artículo $228^{\circ}$}

El Art. $228^{\circ}$ establecía la entrega por Alemania a los aliados de "las personas acusadas de haber cometido actos contrarios a las leyes y a los usos de la guerra", i.e., a los súbditos alemanes acusados de crímenes de guerra para su procesamiento por los tribunales militares nacionales de las potencias aliadas interesadas. En realidad, no se aplicó este artículo pues Alemania se negó a extraditar a sus nacionales.

Los aliados crearon una entidad ex-profeso, la «Comisión decisoria sobre las responsabilidades de los autores de la guerra y sobre la aplicación de sanciones por la violación de las leyes y costumbres de la guerra" (la Comisión Aliada, creada en 1919). La Comisión Aliada emitió un informe en febrero de 1920 por el cual exigió a Alemania la entrega de 896 pretendidos criminales de guerra para juzgarlos, aunque después la lista se redujo (por razones políticas) a 45 acusados ${ }^{56}$.

Mas, Alemania decidió procesar ella misma a los acusados mediante ley del 18 de diciembre de 1919 que concedió al Tribunal del Reich (Reichsgericht), con sede en Leipzig, una competencia de excepción para procesar a los presuntos criminales de guerra (en 1922 rechazaría otros pedidos de extradición de los aliados). Sólo se juzgó a doce de los acusa-

55 Entre los crímenes de guerra alemanes se podrían incluir: posiblemente, los bombardeos a París con artillería de largo alcance (quebrantamiento del principio de distinción); la guerra submarina ilimitada declarada en 1917 (Declaración de Londres de 1909: poner en lugar seguro a pasajeros y tripulación de barcos mercantes o de pasajeros); los bombardeos con dirigibles a Londres (prohibición de la Declaración de La Haya de 1899, IV Convención de La Haya); ataque a la navegación neutral (Derecho de Neutralidad en Guerra Marítima); uso de gases tóxicos en Ypres en 1915 y Verdún en 1916 (prohibidos en la Declaración de La Haya de 1899); división administrativa de Bélgica en Flandes y Valonia en 1917, separación de la Polonia rusa en 1916 y de Ucrania en 1918 como Estados independientes en perjuicio de Rusia (prohibido por el Derecho de Ocupación Beligerante). Empero, los aliados también violaron el Derecho de Guerra: uso de gases asfixiantes en Verdún en 1915 y en el Somme en 1916; lucha sin cuartel y matanza de prisioneros turcos por T.E. Lawrence en 1918; bloqueo a larga distancia de Alemania por Londres; raids aéreos aliados contra Tréveris, Stuttgart, Karlsruhe, Friedrichshafen (Alemania) y Liubliana (Austria-Hungría).

56 Cherif Bassiouni, Derecho penal internacional (Madrid: Tecnos, 1984), p. 62. 
dos. Fueron juzgados en los procesos de Leipzig en $1921^{57}$. De los doce, resultaron absueltos seis.

\section{Artículo 2290}

El Art. $22^{\circ}$ tenía previsto que los aliados crearían tribunales militares nacionales aliados para castigar los crímenes de guerra. Para algunos autores esta disposición no tiene valor de precedente jurídico válido, pues dichos tribunales se basaban en el principio de personalidad pasiva (o de nacionalidad de las víctimas) para ejercer jurisdicción sobre los acusados (principio no reconocido por la mayoría de los Estados) $)^{58}$.

\subsubsection{Crímenes contra la humanidad}

\section{Posición de los Aliados}

En 1919, la Comisión Aliada recomendó que aquellos que habían violado las «leyes de la humanidad» debían ser castigados.

Esto era en referencia implícita a los sucesos acaecidos en febrero-abril de 1915, cuando se perpetró la masacre turca contra su minoría armenia (que culminó en un 1.000.000 muertos, pues los turcos no los consideraban como fieles al Estado ${ }^{59}$ ). Esta masacre fue denunciada en la Declara-

57 Los procesos más célebres fueron The Dover Castle (1923-1924) y The Llandovery Castle (1923-1924).

58 Alicia Gil Gil, El genocidio y otros crímenes internacionales (Valencia, España: Centro Francisco Tomás y Valiente, 1999), p. 35.

59 El imperio turco gobernado por el régimen autoritario del sultán Abdul Hamid II (1876-1909) permitía las depredaciones de los kurdos contra los armenios. Esta situación condujo al estallido de una rebelión armenia en 1894 . En respuesta, el régimen turco desencadenó una campaña de exterminio de la población armenia en 1894-1896. Después, el movimiento nacionalista de los "Jóvenes Turcos» (constituido principalmente por jóvenes estudiantes y militares), que buscaban la eliminación del régimen decadente imperante del sultán y el resurgimiento de una nueva Turquía fuerte, tomaron el poder mediante revolución en 1908. Durante la guerra, ellos decidieron poner en marcha un plan de verdadero exterminio del grupo minoritario armenio, impulsados por sus fanáticos principios de unificación étnica y religiosa del En este genocidio, actuaron también batallones de guerreros kurdos como verdugos. En conjunto se estima que perecieron en las matanzas de 1915 más de 1.000 .000 de armenios. Vid., "Turquía del imperio a la república: la revolución turca», en: Nicolás Gibelli (dir.), Historia de las revoluciones, t. 3 (Buenos Aires: Cuántica, 1973), pp. 649-672. 
ción aliada del 28 de mayo de 1915 (emitida por Rusia, Francia y Gran Bretaña) como "crimen contra la humanidad y la civilización", por el cual debían responder los miembros del gobierno turco y sus agentes implicados en la masacre.

El genocidio armenio no podía considerarse como crimen de guerra, pues el Derecho de Guerra no se aplicaba a las relaciones entre un gobierno y sus propios nacionales, aún cuando conformen grupos étnicos diferenciados o grupos políticos de oposición. Para los aliados, el crimen contra la humanidad no fue considerado como ley post factum, pues el preámbulo de la IV Convención de La Haya de 1907, la Cláusula Martens, explícitamente prescribe que todos deben actuar conforme a las «leyes de la humanidad $"{ }^{60}$.

\section{Intención de la Cláusula Martens}

Sin embargo, débese notar que la Cláusula fue diseñada originalmente para suministrar reglas humanitarias complementarias para la protección de la población civil de los territorios ocupados ${ }^{61}$, y no pretendía indicar un conjunto de normas diferentes del Derecho de Guerra (según es contemplado en las Convenciones de La Haya). Fue designada para proteger en sentido humanitario en tiempos de guerra (principio de humanidad o humanitario) y no para proteger al género humano (la humanidad) en toda circunstancia, como lo hacen los Derechos Humanos. Desde entonces, durante el transcurso del siglo XX, ha emergido un amplio consenso en el sentido que la Cláusula Martens alcance todos los ámbitos del Derecho Internacional Humanitario latu sensu (o Derecho de los Conflictos Armados).

\section{Formulación de la acusación}

Así, la comunidad internacional y el Derecho Internacional por vez primera formularon el cargo de "crímenes contra la humanidad" cuando

60 Para un estudio autorizado sobre la Cláusula Martens y las "leyes de humanidad", vid., Theodor Meron, The Martens Clause, Principles of Humanity, and Dictates of Public Conscience, American Journal of International Law 94, 1 (enero del 2000): 78-89.

61 T. Meron, op. cit., p. 79. 
el Tratado de Sèvres de $1920^{62}$ (tratado de paz entre Turquía y los Aliados), Art. $230^{\circ}$, tenía previsto el juzgamiento de los responsables de la masacre cometida durante la guerra en el territorio del imperio turco por un tribunal ad hoc creado por la Sociedad de las Naciones o por las propias potencias aliadas (mientras, los arts. $226^{\circ}-228^{\circ}$ tenían previsto la sanción a los criminales de guerra turcos). Empero, nunca hubo alguna petición por parte aliada para la entrega de individuos ${ }^{63}$.

La recomendación para juzgar (a «los culpables de delitos contra las leyes y costumbres de la guerra o las leyes de la humanidad") ${ }^{64}$ presentada por la Comisión Aliada a la Conferencia Preliminar de Paz fue finalmente rechazada y no sería sino hasta el estatuto de Nüremberg que la sanción a los crímenes contra la humanidad fue reconocida finalmente en el DI positivo $^{65}$.

Su sucesor, el Tratado de Lausana de 1924, no contenía ninguna previsión sobre el castigo de los criminales de guerra sino una declaración de amnistía. $^{66}$

\subsubsection{El Tribunal Militar Internacional de Nüremberg}

Más adelante, como se sabe, el particular desarrollo y desenlace de la Segunda Guerra Mundial (1939-1945), y la magnitud de los crímenes perpetrados, hizo posible la creación efectiva de distintos tribunales penales internacionales en Nüremberg y Tokio para juzgar a los altos dirigentes de Alemania y Japón ${ }^{67}$.

62 Las objeciones de los Estados alegando la vaguedad de las «leyes de las humanidad" impidieron la adopción de las recomendaciones de la Comisión Aliada para incorporar el crimen contra la humanidad en el Tratado de Versalles, en el caso de Alemania.

63 Bert V. A. Röling, "The Law of War and the National Jurisdiction Since 1945", Recueil des Cours de l'Academie de Droit International, t. 100-II (1960), pp. 345-346.

64 Margaret McAuliffe de Guzman, "The Road from Rome: the Developing Law of Crimes against Humanity", Human Rights Quarterly 22 (mayo del 2000): 344.

65 McAuliffe deGuzman, op. cit., p. 344.

66 Alicia Gil Gil, El genocidio y otros crimenes internacionales (Valencia: Centro Francisco Tomás y Valiente, 1999), p. 34. Desgraciadamente, esto fue uno de los alicientes que Hitler consiguió. Después, él comentaría que si el mundo pudo olvidar el genocidio de los armenios (un millón de muertos), también podría olvidar el que se proponía efectuar, el de los judíos (seis millones).

67 Sin embargo, es necesario recordar que aparte de los tribunales militares internacionales de Nüremberg y de Tokio creados para juzgar a los máximos dirigentes alemanes y 
El Acuerdo de Londres para el Procesamiento y el Castigo de los Grandes Criminales de Guerra del Eje Europeo del 8 de agosto de 1945 tuvo como anexo el Estatuto del Tribunal Militar Internacional (las cuatro grandes potencias aliadas suscribieron dicho tratado, mientras que diecinueve Estados aliados más se adhirieron después al Acuerdo). El Tribunal tuvo como sede la ciudad de Nüremberg ${ }^{68}$. Según este tratado, un tribunal con cuatro jueces titulares (más cuatro jueces suplentes) designados por las cuatro potencias vencedoras debía establecerse.

\subsubsection{Fundamento jurídico para su creación}

La decisión de llevar ante la justicia a los criminales de guerra nazis fue adoptada por los Aliados al comienzo de la Segunda Guerra Mundial, primero en Polonia ${ }^{69}$ y después en Yugoslavia ${ }^{70}$.

Los primeros exterminios de los judíos provocaron una ratificación al respecto (tras la invasión de Rusia): El 13 de enero de 1942, los aliados redactaron la Declaración del Palacio de St. James, Londres (China y la URSS firmaron después la declaración), sobre la sanción de los criminales de guerra.

En octubre de 1942, se creó en Londres la «Comisión de Crímenes de Guerra de las Naciones Unidas» (análoga a la comisión aliada de la Gran Guerra) con apoyo de EEUU, Gran Bretaña y otros 15 Estados aliados ${ }^{71}$.

japoneses, fueron también creados diversos tribunales militares aliados para juzgar a los demás dirigentes del Eje, así como otros tribunales que juzgaban a sus nacionales por su colaboración con las potencias del Pacto Tripartito.

68 La elección de Nüremberg como sede no respondía a un deseo aliado de que los acusados fueran juzgados en el mismo lugar de sus triunfos. Los soviéticos hubieran elegido Berlín y los ingleses Munich. Pero, el general L. Clay, comandante adjunto de la zona americana de ocupación en Alemania, sugirió al juez Jackson la ciudad de Nüremberg. En una ciudad casi totalmente destrozada por los bombardeos, se conservaba, milagrosamente, el palacio de Justicia, así como el edificio construido por Hitler para sus invitados a los congresos del partido nazi, donde podían alojarse los funcionarios. Los periodistas fueron albergados en el castillo Stein, en las cercanías. Vid., Eddy Bauer, Historia de la Segunda Guerra Mundial, vol. X (Pamplona: Salvat, 1984), p. 286.

69 Por ejemplo, bombardeo y destrucción de Varsovia en setiembre de 1939.

70 Comenzando por el bombardeo indiscriminado de Belgrado del 6 de abril de 1941, y después las cruentas represalias contra las acciones de los partisanos.

71 Vid., Eddy Bauer, Historia de la Segunda Guerra Mundial, vol. X (Pamplona: Salvat, 1984), p. 281. 
En la «Declaración de Moscú de las Tres Potencias sobre las Atrocidades Alemanas» del 30 de octubre de 1943, suscrita por EEUU, la URSS y Gran Bretaña (en nombre de las 35 naciones aliadas) ${ }^{72}$, los aliados decidieron que harían una distinción entre los criminales de guerra menores (a ser procesados en los países donde hubieran cometido los crímenes, ratificado después por el Acuerdo de Londres, Art. $4^{\circ}$ ) y los grandes criminales que serían juzgados por un tribunal interaliado $a d h o c^{73}$.

En las Conferencias de Yalta (febrero de 1945) y de Potsdam (julio de 1945), los Aliados reafirmaron su voluntad de juzgar los crímenes nazis.

El acuerdo entre los Aliados para lograr superar los obstáculos que impedían concretar dicho consenso fue mérito de Robert Jackson (juez de la Corte Suprema de Justicia de EEUU y futuro fiscal americano en Nüremberg).

\section{El Acuerdo de Londres}

Finalmente, el Acuerdo de Londres del 8 de agosto de 1945 adoptó el estatuto del tribunal militar internacional. El tribunal debía juzgar a los grandes criminales por cuatro cargos distintos:

(a) Conjura (complot contra la paz): por desarrollar un plan para desencadenar guerras de agresión.

(b) Crímenes contra la paz: los acusados habían violado 34 tratados y desencadenado guerras de agresión.

(c) Crímenes de guerra: los acusados habían ordenado o permitido asesinatos masivos, tortura, deportaciones y organizado el pillaje económico.

72 Vid., Hans-Heinrich Jescheck, «Nuremberg Trials», en: R. Bernhardt (ed.), Encyclopedia of Public International Law, vol. III (1997), p. 748. Empero, Gil señala que Roosevelt, Churchill y Stalin firmaron el 30 de octubre de 1943 la Declaración de Moscú. Cf., A. Gil Gil, El genocidio y otros crímenes internacionales (Valencia: Centro Francisco Tomás y Valiente, 1999), p.36. Sin embargo, los Tres Grandes sólo se encontrarían por vez primera en la Conferencia de Teherán el 28 de noviembre de 1943 (nunca se reunieron los tres en la capital soviética). Cf., A.J.P. Taylor, "La guerra en la cumbre», en: B. Pitt y B. Liddell Hart, Así fue la Segunda Guerra Mundial (Buenos Aires: ANESANoguer-Rizzoli, 1972), pp. 225-233; y Eddy Bauer, Historia de la Segunda Guerra Mundial (Pamplona: Salvat, 1979), pp. 46-62.

73 La jurisdicción para sancionar a los criminales menores se basaría en el principio de territorialidad. 
Augusto Hernández Campos

(d) Crímenes contra la humanidad: los acusados habían perseguido minorías y exterminado colectividades.

El proceso se inició el 20 de noviembre de 1945 y finalizó el 31 de agosto de 1946, el Tribunal dictó sentencias el 30 de setiembre y el 1 de octubre de 1946. Las sentencias se hicieron efectivas el 16 de octubre de 1946.

Se procesarían a 24 individuos y 6 organizaciones (los arts. $9^{\circ}-10^{\circ} \mathrm{del}$ estatuto permiten que organizaciones sean declaradas criminales). De los 24, sólo 21 individuos comparecerían ante el tribunal, pues Martin Bormann fue juzgado in absentia (Art. $12^{\circ}$ del estatuto permitía juicios en rebeldía ${ }^{74}$, Robert Ley $^{75}$ se suicidó antes del inicio del proceso y Gustav Krupp von Bohlen und Halbach ${ }^{76}$ fue declarado demente senil.

Entre las seis organizaciones y estamentos se encontraban autoridades estatales alemanas como el Gobierno del Reich y el Alto Mando de la Wehrmacht $\left(\mathrm{OKW}^{77}\right)$; así como las entidades que estuvieron más

74 Bormann, jefe de la cancillería del partido nazi y secretario de Hitler, eminencia gris del régimen, desapareció el 1 de mayo de 1945, al término de la batalla de Berlín, se pensó que había huido a Sudamérica (como Mengele en Paraguay y Brasil, Barbie en Bolivia, Eichmann en Argentina). Las contradictorias versiones acerca de su fin llevaron a los Aliados, en el período preparatorio del proceso de Nüremberg, a concluir que Bormann vivía. Así se formalizó la acusación y durante semanas se le conminó a través de las emisoras de radio de las cuatro zonas de ocupación a que se presentase ante las autoridades aliadas. En total se distribuyeron 200.000 carteles con su nombre. Sin embargo, el lugar que tendría que haber ocupado en el banquillo de acusados permaneció vacío. Al dictar sentencia los jueces, se le encontró culpable de dos cargos de gravedad máxima: crímenes de guerra y crímenes contra la humanidad. En realidad como había afirmado un testigo ocular Bormann había muerto al final de la Batalla de Berlín. Esta afirmación fue confirmada cuando se descubrió su cadáver en 1972 durante unas construcciones en Berlín Occidental. Vid., Harald Steffahn, "Martin Bormann: La eminencia parda", en: C. Zentner (ed.), El Tercer Reich, t. IV (Buenos Aires: ANESA-Noguer), pp. 472-475.

75 R. Ley, jefe del Frente Alemán del Trabajo-DAF (entidad que estaba a cargo de la organización sindical nacional, tras la prohibición de los sindicatos libres) desde 1933, se suicidó el 26 de octubre de 1945.

76 Presidente del consorcio de los Krupp. Bertha Krupp, su esposa, era la propietaria.

77 OKW, Oberkomando der Wehrmacht, del alemán "Alto Mando de la Wehrmacht». La "Wchrmacht" (del alemán, "Fucrza de Defensa») era la denominación oficial desde 1935 de las fuerzas armadas alemanas del III Reich, su jefatura (el OKW) fue creada por Hitler en febrero de 1938, a raíz de crisis Blomberg-Fritsch (con el fin de controlar más completamente a las fuerzas armadas). Fue la sucesora de la Reichswehr ("Defensa del Imperion), denominación del ejército de la República de Weimar. 
involucradas en las políticas criminales del Tercer Reich como las SS, las SA, el SD y la Gestapo.

2.2.2.2. La cuestión de la responsabilidad del individuo por crímenes contra la paz

Los crímenes contra la paz se hallaban incluidos en el Art. $6^{\circ}$, inc. a, del estatuto.

\section{(A) POSICION DE LA DEFENSA}

La defensa apeló al principio clásico de irretroactividad de la ley penal (referido por los expertos legales en el adagio latino de nullum crimen, nulla poena sine lege).

No existía ningún precedente relevante penal bajo el DI consuetudinario. Aunque el punto de vista general es que el DI consuetudinario emerge de la práctica y de la opinio iuris, no existía, antes de 1945, una práctica de castigar a jefes de gobierno o miembros de gobierno por desencadenar una guerra ${ }^{78}$; se consideraban así protegidos por la doctrina de inmunidad de Estados (debido a su capacidad oficial poseen inmunidad soberana frente a la jurisdicción de otros Estados) y la doctrina del acto de Estado (los actos de un Estado soberano no pueden ser juzgados por tribunales de otros Estados).

\section{(B) POSICION DEL TRIBUNAL}

Una fuerte objeción estribaba en la validez de cargo de crímenes contra la paz. El juez Jackson, en ausencia de precedentes jurídicos, invocó una costumbre que se basaba en la Declaración de la Sociedad de las Naciones (SDN) del 24 de setiembre de 1927 y en el Pacto Briand-Kellogg de 1928 que declaraban a la guerra como ilegal. También, el Tratado de Versalles que declaró a Alemania responsable de la guerra y su Art. 227º había previsto la creación de un «Alto Tribunal» para juzgar al kaiser ${ }^{79}$.

Cualquier violación del tratado de 1928 era una violación del DI. En consecuencia, Alemania, según los principios de responsabilidad internacional, incurría en responsabilidad como Estado. ${ }^{80}$

78 C. Tomuschat, "From Nuremberg to The Hague», Law and State, vol. 53-54 (1996), p. 116.

79 Vid., Eddy Bauer, Historia de la Segunda Guerra Mundial, vol. X (Pamplona: Salvat, 1984), pp. 282-284.

80 Tomuschat, op. cit., p. 116. 
Empero, queda la cuestión que si adicionalmente debía imponerse sanciones penales a los individuos.

Este tribunal declaró que la ilegalidad de la guerra implicaba la responsabilidad penal de aquellos individuos que planearon, prepararon y dirigieron una guerra, por lo que todas las acciones de un Estado fueron realizadas por individuos y no por entidades abstractas (según el art. $7 \mathrm{del}$ estatuto del Tribunal, la inmunidad soberana de los Estados se vuelve irrelevante cuando se quebranta gravemente el DI). En su sentencia dictada el 30 de setiembre de 1946, el Tribunal de Nüremberg señaló al respecto

"Los crímenes contra el derecho internacional son cometidos por los hombres, no por entidades abstractas, y sólo mediante el castigo a los individuos que cometen tales crímenes pueden hacerse cumplir las disposiciones del derecho internacional... El principio de derecho internacional que, en ciertas circunstancias, protege a los representantes de un Estado, no puede aplicarse a los actos que tal derecho condena como criminales.. ${ }^{81}$

Sin embargo, como puede observarse, el fundamento jurídico para los crímenes contra la paz no era incontestable.

\subsubsection{Crímenes de guerra}

Durante los procesos después de la Primera Guerra Mundial, la defensa alegó, frente a las acusaciones de crímenes de guerra, el argumento de la "obediencia debida a órdenes superiores», pues el DI no había exceptuado ni invalidado de forma expresa esta teoría ${ }^{82}$.

Como consecuencia del art. 8 del estatuto, que consagraba la irrelevancia de la doctrina del acto de Estado, nadie podría eludir su responsabilidad en base al argumento de las "órdenes superiores" como defensa.

No obstante, esto no pudo validar el hecho que estos artículos $7^{\circ}$ y $8^{\circ}$ del estatuto no tuvieran otro fundamento que la uderivada de su extrapolación de una práctica histórica limitada, que no constituía prueba

81 Sentencia del Tribunal de Nüremberg, cit. en Max Sorensen (ed.), Manual de derecho internacional público (México: FCE, 1985), p. 493.

82 C. Bassiouni, Derecho penal internacional (Madrid: Tecnos, 1984), p. 64. 
bastante de una práctica consuetudinaria internacional. Por otro lado, nunca se habían fijado penas para las violaciones en cuestión. ${ }^{83}$

En consecuencia, cabe afirmar que las penas impuestas infringieron el principio de nulla poena sine lege.

\subsubsection{Crímenes contra la humanidad}

El estatuto del Tribunal (Art. $6^{\circ}$, inc. c) establecía una tercera categoría de crímenes definidos como crímenes contra la humanidad. Aunque esta categoría de crímenes ya había sido formulada en la Gran Guerra, no fue considerada por el DI sino hasta la creación del Tribunal de Nüremberg cuando se reconoció definitivamente, a través de su estatuto y sentencia, la prohibición de los crímenes contra la humanidad en el DI positivo ${ }^{84}$.

Muchos de los crímenes cometidos por el régimen nazi no podían caracterizarse como crímenes de guerra, pues este concepto siempre requiere una relación concreta con un acto de guerra. Por ejemplo, la persecución y exterminio de los judíos en Alemania no calificaría como crímenes de guerra. Tampoco las deportaciones y persecuciones perpetradas, por ejemplo, en Checoslovaquia ${ }^{85}$, Austria, Hungría y Dinamar$\mathrm{ca}^{86}$

Con el fin de abarcar todos los crímenes de grandes proporciones debía ser creado un nuevo tipo de crimen con nuevos elementos.

Para el Tribunal, los crímenes contra la humanidad (esclavitud, maltratos, persecución de minorías, deportación masiva, genocidio, asesinato) debía hallarse en los derechos penales internos de cada Estado. Pues, en ninguno de estos sistemas jurídicos internos dichos crímenes están exceptuados de castigos, no se puede hablar de sociedad humana alguna donde ocurra estos crímenes y no sean punibles.

83 Bassiouni, op. cit., p. 65.

84 M. McAuliffe de Guzmán, "The Road from Rome: The Developing Law of Crimes against Humanity", Human Rights Quarterly 22 (mayo 2000): 344.

85 Por ejemplo, la destrucción de Lidice en 1942 y las represalias desatadas tras la muerte de Heydrich, jefe del SD y Reichsprotektor de Bohemia y Moravia.

86 Esto se debía a que formalmente Alemania no estaba en estado de guerra con estos países, demostrado con la declaración de guerra (por que no se aplicaría el Derecho de Guerra). Tampoco lo estaba, por ejemplo, con Estonia, Letonia y Lituania. 


\section{Controversia}

Hubo debate en las negociaciones conducentes a la inclusión en el estatuto de los crímenes contra la humanidad respecto a que si violó el principio de nullum crimen sine lege.

Para los aliados la situación era que si bien la inclusión de este crimen en el estatuto representaba un importante desarrollo innovador en el derecho internacional, éste estaba firmemente fundamentado en el derecho consuetudinario y por tanto no violaba el principio de legalidad. Los nazis al perpetrar crímenes contra la humanidad violaron los «principios generales de derecho", ergo eran sancionables al igual que los crímenes de guerra $^{87}$.

La sentencia de Nüremberg también adoptó el punto de vista que el Estatuto del Tribunal era declaratorio del DI consuetudinario expresando que:

«el Estatuto no es un ejercicio arbitrario de poder por parte de las Naciones victoriosas, sino ... que es la expresión del derecho internacional existente en el momento de su creación; y que para tal fin es en sí mismo una contribución al derecho internacional». ${ }^{88}$

En realidad, la persecución y sanción de los crímenes contra la humanidad fue una novedad ante el Derecho Penal Internacional, y supuso en consecuencia una incriminación ex post facto.

\subsubsection{Las jurisdicciones ratione personae y ratione materiae}

Por otra parte, para evitar que la defensa alemana mencionara crímenes aliados, el juez Robert Jackson propuso la inserción, en el estatuto, de la obligación de limitar el debate a las acciones de los acusados.

El tribunal, siendo de vencedores, tenía por finalidad, según su competencia ratione personae y ratione materiae, juzgar a los mayores criminales de guerra del Eje europeo (art. 1 del estatuto), y por tanto enjuiciar sus crímenes.

En consecuencia, no había intención de los Aliados de procesar los crímenes cometidos por sus propios nacionales.

87 M. McAuliffe de Guzmán, "The Road from Rome: The Developing Law of Crimes against Humanity", Human Rights Quarterly 22 (mayo 2000), p. 344.

88 Sentencia del Tribunal de Nüremberg, cit. por McAuliffe deGuzman, op. cit. 
De conformidad con esta idea básica, el tribunal rechazó como irrelevante las objeciones del argumento tu quoque (el argumento que el vencedor también violó las mismas leyes de la guerra) planteado varias veces por la defensa, objeciones formuladas debido a que acciones similares fueron también cometidas por los Aliados ${ }^{89}$.

\subsubsection{Sobre la validez del tribunal y del proceso}

El proceso contra los jefes nazis tenía en suma tres cuestiones controvertibles.

La primera de ellas, se refería a la independencia e imparcialidad del tribunal, desde que dicho tribunal estuviera conformado sólo por representantes de las cuatro potencias aliadas vencedoras. Pues, no se conformaba según el DI preexistente.

También, en segundo lugar, cabe remarcar que las acusaciones presentadas quebrantaban el principio de legalidad (o juricidad) de los delitos y de las penas, esto era a causa que los delitos habían sido incriminados $e x$ post facto (no eran configurados jurídica y válidamente como crímenes ante el DI cuando fueron cometidos, sobretodo los crímenes contra la paz y contra la humanidad).

Mientras, que en tercer lugar, las penas impuestas infringían el principio de legalidad, concretamente una de sus piedras angulares, el principio de irretroactividad de la ley penal en el axioma de nulla poena sine lege (pues nunca se habían fijado penas para los crímenes en cuestión).

Pese a estos lastres jurídicos que pesaban en cuanto al fundamento y existencia del Tribunal, la opinión pública mundial estaba firmemente convencida que los crímenes nazis debían ser castigados.

89 Entre los crímenes aliados que podrían haber sido objeto de la jurisdicción del Tribunal de Nüremberg figurarían: los bombardeos indiscriminados de la aviación angloamericana contra las ciudades alemanas (e.g., Colonia 1942, Hamburgo 1943, Berlín 1943-1944, Dresde 1945), la masacre del Bosque de Katyn por los soviéticos, la matanza de civiles alemanes cuando el ejército soviético invadió Alemania Oriental en 1945, el Pacto Ribbentrop-Molotov de 1939 (entre Alemania y la URSS) para dividirse Europa Oriental, la orden británica para el hundimiento irrestricto de buques alemanes en el Skagerrat, la invasión de Irán e Irak en 1941, etc. 


\subsubsection{El Tribunal Militar Internacional de Tokio}

La Proclama Especial del Comandante Supremo de la Potencias Aliadas para el Establecimiento de un Tribunal Militar Internacional para el Lejano Oriente, adoptada en Tokio el 19 de enero de 1946. El general Douglas MacArthur, el comandante supremo aliado en Japón, creaba así el tribunal militar internacional de Tokio. Sin duda el modelo de Nüremberg fue valioso en este caso. El Tribunal de Tokio, compuesto por once jueces (Art. $2^{\circ}$ de su estatuto), debía procurar un juicio rápido y justo para castigar a los grandes criminales de guerra de Extremo Oriente.

Se juzgaron a los acusados por tres tipos de crímenes (Art. $5^{\circ}$ del estatuto): contra la paz, de guerra, y contra la humanidad. Estos crímenes fueron subdivididos en cincuenticinco cargos.

Entre los crímenes contra la paz estaban: el Pacto Anti-Komintern de 1936, el Pacto Tripartito de 1940, las guerras de agresión contra China (desde 1931) y contra EEUU (1941).

Pueden citarse como crímenes de guerra, inter alia: la construcción ferroviaria en el río Kwai (Birmania-Tailandia) y la "marcha de la muerte» de Bataán (Filipinas) de abril de $1942^{90}$.

Entre las acusaciones de crímenes contra la humanidad figuraban: la masacre de 18.000 habitantes de Lipa (Filipinas) en febrero de 1945, y la matanza de 400 familias de Haing-Kuo-Chuang (China) en $1943^{91}$.

El estatuto, en su Art. 60, reafirma la irrelevancia de la capacidad oficial del acusado y del argumento de las órdenes superiores.

De 28 acusados que debían comparecer en este proceso, sólo lo hicieron 25 ( 2 murieron y 1 perdió la razón). El proceso se inició el 3 de mayo de 1946 y terminó cuando se pronunció el veredicto en noviembre de 1948.

90 La "marcha de la muerte» fue consecuencia de la rendición de los aliados en la península de Bataán el 9 de abril de 1942. Inmediatamente, unos 78.000 soldados aliados se vieron forzados, obligados por los vencedores, a realizar la marcha en condiciones infrahumanas durante nueve días, en un recorrido de $100 \mathrm{~km}$ entre Mariveles y San Fernando. La responsabilidad de esta tragedia fue descargada en el general M. Homma (comandante del Ejército 14 japonés, conquistador de Filipinas). Vid., John Vader, «El ataque a las Filipinas", en: B. Liddell Hart y B. Pitt, Así fue la Segunda Guerra Mundial (Buenos Aires: ANESA-Noguer-Rizzoli, 1972), p. 50.

91 Vid., Eddy Bauer, Historia de la Segunda Guerra Mundial, vol. X (Pamplona: Salvat, 1984), p. 299. 
Paralelamente al Tribunal Internacional de Tokio, se procesaron a "criminales japoneses menores» en tribunales nacionales. Destacan por su aporte a la jurisprudencia y la doctrina, los tribunales estadounidenses: tribunales o comisiones militares (en especial, las establecidas en China y Filipinas) y la Corte Suprema de Justicia de EEUU.

\subsubsection{Otros procesos contra el Eje}

\section{Tribunales aliados en las zonas de ocupación alemanas}

Aparte del proceso de los "grandes criminales" ante el tribunal internacional, se realizaron procesos especiales de altos funcionarios alemanes ("criminales menores") conforme a la Declaración de Moscú y al Acuerdo de Londres.

Tales procesos se efectuarían en las cuatro zonas de ocupación aliadas conforme a la «Ley No 10 del Consejo Interaliado de Control sobre Alemania” del 20 de diciembre de 1945 (que fue emitida por las cuatro potencias para unificar los principios que debían guiar a la represión de los crímenes de guerra) para enjuiciar grupos especiales de acusados. Indudablemente, el estatuto del Tribunal Internacional sirvió de base para su actividad.

Así, EEUU llevó a cabo, en su zona de ocupación, doce procesos ante tribunales militares americanos en Nüremberg en 1947-1949.

Gran Bretaña, también en su zona de ocupación, procesó ante sus tribunales militares, inter alia: al mariscal Erich von Manstein ${ }^{22}$ en Hamburgo y al general Nikolaus von Falkenhorst (comandante del ejército alemán en Noruega) en Werl; también al general Kurt Student ${ }^{93}$ en Luneburgo en 1946 (por la orden de los comandos); igualmente en Luneburgo, fueron condenados a muerte, miembros del personal del campo de concen-

92 A juicio de uno de los más connotados historiadores militares del siglo XX, Sir Basil Liddell Hart, Manstein era el mayor genio militar y el mayor peligro que tuvieron que enfrentar los Aliados en la Segunda Guerra Mundial.

93 K. Student, comandante de las fuerzas paracaidistas alemanas durante la Segunda Guerra Mundial. Fue procesado ante el tribunal militar británico de Luneburgo por su implicancia en la «orden de los comandos» dictada por Hitler y que tenía previsto la ejecución de todos los soldados aliados integrantes de las unidades de comandos que cayesen prisioneros, en clara violación de las Convenciones de La Haya de 1907 y de Ginebra de 1929. 
tración de Bergen-Belsen, tales como el Dr. Fritz Klein y la guardiana Irma Greese.

\section{Tribunales aliados en otros países}

También los aliados establecieron sus tribunales militares nacionales en otros países, aparte de Alemania y Japón, para juzgar a otros nacionales del Eje.

Por ejemplo, en Italia, tribunales militares británicos procesaron y condenaron a muerte al mariscal Albert Kesselring en Venecia en $1947^{94} \mathrm{y}$ al general Eberhard von Mackensen en Roma en $1946^{95}$.

En China, el tribunal militar norteamericano de Shanghai condenó a alemanes miembros de la embajada y consulados de Alemania en China en enero de $1947^{96}$. En Filipinas, tribunales militares americanos realizaron juicios, de ellos los procesos más célebres fueron contra los generales japoneses Tomoyuki Yamashita y Masaharu Homma en 194697.

\section{Tribunales en los países aliados}

Asimismo, en los países aliados se llevaron a cabo procesos contra individuos nacionales del Eje o súbditos de los Aliados que fueron colaboracionistas.

En Francia, por ejemplo, tribunales procesaron en París al mariscal Henri Pétain ${ }^{98}$ y a Pierre Laval en $1945^{99}$. Holanda procesó y condenó a

94 Kesselring (comandante de las fuerzas armadas alemanas en Italia) fue condenado a muerte, mas fue después indultado en 1952.

95 Mackensen (comandante en jefe del Ejército 14 alemán en Italia) fue acusado de corresponsabilidad de la masacre de las Fosas Ardeatinas (cerca de Roma, marzo de 1944) y condenado a muerte. La pena fue conmutada por la de cadena perpetua. Después, se redujo la condena a 25 años de prisión y finalmente liberado en 1952.

96 El tribunal sostuvo que la capitulación del Reich del 7 de mayo de 1945 era obligatoria para todos los ciudadanos alemanes civiles o militares.

97 Ambos casos han sido criticados por establecer un criterio sin precedentes respecto a la "responsabilidad de mando por crimen por omisión", i.e., que los generales en cuestión debían haber conocido e impedido los crímenes de guerra cometidos por sus subodinados. Yamashita (por las masacres contra civiles cometidas por tropas niponas en Filipinas cuando su liberación por los norteamericanos en octubre de 1944-setiembre de 1945) y Homma (por su responsabilidad en la «marcha de la muerte» de Bataán de abril de 1942) fueron condenados a muerte y ajusticiados.

98 Pétain (jefe del «Estado francés»), condenado a muerte por colaborar con los nazis 
muerte a Anton Mussert (jefe del partido nazi holandés) en 1945. Mientras, Bélgica, en 1945, condenó a muerte in absentia a Léon Degrelle (comandante de la Legión Valonia de las SS). Por su parte, tribunales yugoslavos procesaron a nacionales suyos como Draza Mihailovic (jefe de los chetniks) en 1946, Milan Nedic (jefe del Estado títere de Serbia) murió antes del inicio de su juicio en 1946, y, en rebeldía, a Ante Pavelic (líder de la Croacia independiente); también nacionales del Eje entre ellos al general Alexander Löhr ${ }^{100}$. URSS procesó al general Andrei Vlassov (creador de un ejército ruso anticomunista) en Moscú en 1946. Mientras, Noruega enjuició a Vidkun Quisling (jefe del gobierno noruego pro-nazi) en Oslo y lo condenó a muerte (ejecutado en octubre de 1945). En Londres, fue condenado a muerte el 19 de setiembre de 1945, después de tres días de juicio, William Joyce (alias Lord Haw Haw) por alta traición.

\section{Tribunales de los antiguos países del Eje}

Después de la guerra, también en los antiguos países del Eje se realizaron procesos contra criminales de guerra.

Rumania procesó y condenó a muerte en 1946 al mariscal Ion Antonescu y también, en rebeldía, a Horia Sima (jefe de la Guardia de Hierro y fundador de un gobierno rumano pro-nazi en el exilio en agosto de 1944).

Bulgaria juzgó a los tres regentes que gobernaron el país tras el deceso de Boris III; el príncipe Cirilo, el primer ministro Filov y general Michov fueron condenados a muerte y ejecutados en febrero de 1945. Finlandia decidió enjuiciar a Risto Ryti, ex-presidente de la república, por haber declarado la guerra a la URSS y condenarlo en 1946 a diez años de pri-

el 15 de agosto de 1945, fue indultado por De Gaulle en vista de su historial militar, y conmutada su sentencia a cadena perpetua. Murió en prisión en 1951.

99 Laval (primer ministro de la Francia de Vichy), escapó a España al final de la guerra, empero fue entregado a los americanos y después a los franceses que lo condenaron a muerte y ejecutado en octubre de 1945 . Otros procesos contra franceses colaboracionistas incluyen los realizados contra Darnand (condenado a muerte), el almirante Esteva (condenado a cadena perpetua), y el general Dentz.

100 Fue condenado a muerte y ejecutado en 1947 por su participación en el ataque aéreo contra Belgrado en 1941. 
sión ${ }^{101}$. Italia procesó al mariscal Rodolfo Graziani (ministro de Guerra de la república neofascista) en 1950.

Alemania ha llevado a cabo, después de los procesos aliados de 19451949, juicios continuos contra sus nacionales acusados de crímenes en dicha guerra ${ }^{102}$. Tiempo después, Israel procesaría a Adolf Eichmann ${ }^{103}$ en Tel Aviv en 1961, quien sería ajusticiado en 1962. Francia procesaría a Klaus Barbie en 1987, a Maurice Papon procesado en 1997 acusado por la deportación y muerte de 1500 judíos en 1942-1944; e Italia a Erich Priebke y Karl Haas detenidos en 1995 y procesados en 1996-1997 por su participación en la masacre de las Fosas Ardeatinas ${ }^{104}$.

\subsubsection{El Tribunal de la Antigua Yugoslavia}

Después de la Guerra Fría, y ante las especiales circunstancias geopolíticas, de una parte, y humanitarias, de otra, que caracterizaron los conflictos armados de la antigua Yugoslavia y de Ruanda, fue el Consejo de Seguridad de la ONU el que, mediante resoluciones decidió crear sendos tribunales penales internacionales para juzgar a los violadores del Derecho Internacional Humanitario (Derecho de Guerra o Derecho Internacional de los Conflictos Armados ${ }^{105}$ ) en aquellas guerras.

101 Fue puesto en libertad en 1949.

$102 \mathrm{El}$ mariscal Ferdinand Schörner fue condenado en Munich en 1955 a cuatro años de prisión. En 1962, el general de las SS, Erich von dem Bach-Zelewski (que reprimió la insurrección de Varsovia en 1944) fue condenado en Nüremberg a cadena perpetua.

103 Eichmann, coronel de las SS, fue encargado de la ejecución de la "solución final», fase culminante de la política de antisemitismo del Tercer Reich (desatada oficialmente con las Leyes Raciales de Nüremberg de 1935), decisión que se tomó en la conferencia secreta de Wannsee (Berlín) del 20 de enero de 1942 bajo la presidencia de Heydrich por encargo de Goering. Por tanto, Eichmann fue el principal responsable del exterminio de la población judía en toda la Europa ocupada por los nazis.

$104 \mathrm{Vid}$., Jaume Ferrer Lloret, «La aplicación de las normas internacionales sobre la responsabilidad penal del individuo: valoración de la práctica más reciente», Revista IIDH, 27 (enero-junio 1998): 13-14.

105 Según la Cruz Roja, la opinión de la doctrina más autorizada en esta disciplina jurídica, los términos "Derecho Internacional Humanitario» (utilizado en las OI, los gobiernos y las universidades) y "Derecho de Guerra" y "Derecho de los Conflictos Armados" (utilizado por las fuerzas armadas) son sinónimos e intercambiables. Cf., CICR, Derecho internacional humanitario (Ginebra: CICR, [1998]), p. 5. 


\subsubsection{Fundamento jurídico: el caso Tadic}

El Consejo de Seguridad poseía facultad para crear una entidad de esta envergadura. En virtud de los arts. $7^{\circ}$ (pár. 2) y $29^{\circ}$ de la Carta de la ONU, el Consejo podía crear órganos subsidiarios. Mientras, que el Art. $41^{\circ}$ posibilitaba que el Consejo adoptara medidas no coercitivas.

\section{Posición de la defensa}

En el caso Tadi ${ }^{106}$, la defensa planteó que el Consejo de Seguridad había excedido su autoridad pues el Tribunal no era conforme a normas pertinentes de DI y por tanto no podía procesarle ${ }^{107}$.

En la cuestión preliminar sobre la jurisdicción del tribunal, la defensa de Tadic señaló que el tribunal debió ser creado por tratado, que no fue intención expresa de la Carta de la ONU permitir al Consejo de Seguridad crear tribunales judiciales (por tanto estaba actuando ultra vires), que la creación de este tribunal no es consistente con la práctica del Consejo en otros conflictos, y que el tribunal no había promocionado la paz en los Balcanes ${ }^{108}$.

\section{Decisión del Tribunal}

A ello, el Tribunal, en su sentencia del 2 de octubre de 1995 en este mismo caso, afirmó que, según el Art. 39 del Capítulo VII de la Carta, el Consejo de Seguridad determinaría las amenazas a la paz y que, conforme al mismo artículo, los conflictos internos también podían ser consi-

$106 \mathrm{El}$ acusado Dusko Tadic, un serbo-bosnio, fue juzgado por 31 cargos en base a graves quebrantamientos de las Convenciones de Ginebra (Art. $2^{\circ}$ del estatuto), violaciones de las leyes y costumbres de la guerra (Art. $3^{\circ}$ ), y crímenes contra la humanidad (Art. $5^{\circ}$ ). Los cargos abarcaban tortura y asesinato de musulmanes en los campos de prisioneros dirigidos por serbios de Omarska, Karaterm y Trnopolje en Bosnia nor-occidental durante el verano de 1992. Fue hallado culpable y condenado a 20 años de prisión en 1997. Vid., Michael Scharf, "Trial and error: An asessment of the first judgment of the Yugoslavia war crimes tribunal, New York University Journal of International Law and Politics 30, 1-2 (otoño 1997-invierno 1998), p. 167.

107 Sobre el caso Tadic, vid., Christopher Greenwood, "International Humanitarian Law and the Tadic Case», European Journal of International Law 7 (1996), p. 265.

108 Vid., S.D. Murphy, "Progress and Jurisprudence of the International Criminal Tribunal for the Former Yugoslavia", American Journal of International Law 93, 1 (enero 1999), p. 63. 
derados como amenazas a la paz ${ }^{109}$. Mientras, que en virtud del Art. 410, el Consejo podía decidir qué medidas tomar que no impliquen uso de la fuerza.

Respecto a la facultad para crear mecanismos judiciales, indicó que para el Consejo de Seguridad el órgano judicial constituía un mecanismo para desempeñar su propia función del mantenimiento de la paz.

Finalmente, a juicio del Tribunal este mecanismo judicial ha sido creado conforme al principio de Derecho que establece que un tribunal debe ser creado por ley, pues el estatuto del tribunal se basa en el imperio de la ley al ofrecer las garantías previstas por las Convenciones Internacionales de Derechos Humanos y las Convenciones Europea y Americana de Derechos Humanos ${ }^{110}$.

\section{Creación del Tribunal}

Las resoluciones No 808 del 22 de febrero de 1993 (creación de este tribunal) y No 827 del 25 de mayo de 1993 (entrada en vigor de este mecanismo judicial), crearon el tribunal para sancionar las violaciones graves al Derecho Humanitario en la Guerra de la Antigua Yugoslavia de 1991$1995^{111}$.

\subsubsection{Jurisdicción ratione materiae}

Los principales crímenes considerados en el Tribunal para la Antigua Yugoslavia eran: contra la humanidad y de guerra. Los crímenes contra la paz no fueron considerados debido a su extrema complejidad. O’Brien explica acertadamente que:

109 Vid. J. Ferrer Lloret, "La aplicación de las normas internacionales sobre la responsabilidad penal del individuo: valoración de la práctica más reciente», Revista IIDH, no. 27 (enero-junio de 1998), p. 41.

110 Vid., United Nations International Tribunal for the Prosecution of Persons Responsible for Serious Violations of International Humanitarian Law Commitd in the Territory of the Former Yugoslavia since 1991, Case No. IT-94-1-AR72 (caso Fiscal vs. Tadic), 2 de octubre de 1995.

111 Theodor Meron, profesor de Derecho Internacional de la Universidad de Nueva York, ha realizado estudios relevantes sobre el Tribunal para la Antigua Yugoslavia. Al respecto, pueden consultarse sus ensayos, "The Case for War Crimes Trials in Yugoslavia", Foreign Affairs 72, 3 (verano de 1993), pp. 122-135; "Answering for War Crimes: Lessons from the Balkans", Foreign Affairs 76, 1 (enero-febrero de 1997), pp. 2-8. 
"Los crímenes contra la paz fueron apropiadamente omitidos del estatuto yugoslavo. Su inclusión inevitablemente hubiera requerido que el tribunal investigue las causas del conflicto mismo (y las justificaciones emitidas por los combatientes), las cuales hubieran involucrado al tribunal directamente en los asuntos políticos que conforman el conflicto". ${ }^{12}$

\section{(A) CRIMENES DE GUERRA}

Dentro de la jurisdicción de este tribunal se contempla los crímenes de guerra (arts. $2^{\circ}$ y $3^{\circ}$ del estatuto).

\section{Violaciones graves (Art. 20)}

El Art. $2^{\circ}$ contemplaba las «violaciones graves» a las Convenciones de Ginebra de 1949, que constituyen la espina dorsal del moderno Derecho Internacional Humanitario (DIH).

Pese a que estas Convenciones incluyen al "Art. $3^{\circ}$ común» (aplicable en conflictos internos), el Tribunal en su decisión emitida en el caso Tadic (2 de octubre de 1995) señaló que el Art. $2^{\circ}$ del estatuto se aplicaba sólo a delitos cometidos en el transcurso de un conflicto armado internacional ${ }^{113}$.

\section{Violación de las leyes y usos de la guerra (Art. 30)}

Sin embargo, para cubrir lagunas o brechas que permitieran la violación de otras normas no centrales de DIH, se diseñó el Art. $3^{\circ}$ del estatuto, en el cual se incluía la violación a las «leyes o usos de la guerra»; i.e., el Derecho de Guerra (o DIH) convencional o consuetudinario en general.

Cabe destacar dentro de las Convenciones de Ginebra, al Art. $3^{\circ}$ común, aplicable a conflictos armados internos. Mientras que la expresión «leyes o usos de la guerra» (término clásico, sinónimo del Derecho de Guerra o DIH) es lo suficientemente amplia como para incluir al Protocolo II de 1977, aplicable a guerras civiles. Conforme al criterio del tribunal, el Art. $3^{\circ}$ común se ha elevado a la categoría de DI consuetudinario, por tanto estaría incluido en este Art. $3^{\circ}$ del estatuto.

112 James C. O'Brien, "The International Tribunal for Violations of International Law in the Former Yugoslavia", The American Journal of International Law 87, 4 (octubre de 1993), p. 645.

113 S.D. Murphy, op. cit., p. 67. 
La violación del Art. $3^{\circ}$ común puede conducir a la responsabilidad penal individual por crímenes de guerra en conflictos internos, conforme al Art. $3^{\circ}$ del estatuto del Tribunal, tal como éste lo estableció en los casos Tadic ${ }^{114}$ y Furundzija. ${ }^{115}$

De este modo, toda violación de las Convenciones de Ginebra de 1949 en particular y de las reglas del Derecho de los Conflictos Armados en general, se consideraría como crimen de guerra, ergo sería objeto del tribunal.

\section{(B) CRIMENES CONTRA LA HUMANIDAD}

El estatuto del Tribunal para la Antigua Yugoslavia constituye la codificación más reciente del derecho sobre los crímenes contra la humanidad (Art. $5^{\circ}$ del estatuto). La definición de este estatuto refleja los mayores desarrollos en este derecho desde el estatuto del Tribunal de Nüremberg. Primero, el estatuto del Tribunal para la Antigua Yugoslavia incluye la violación sexual como uno de los crímenes (empero, el estatuto del Tribunal de Nüremberg incluía la violación considerándola un «acto inhumano»). En los casos Tadic y Campo Celebici, el Tribunal determinó que la violación sexual, como medio de la «limpieza étnica», era una crimen contra la humanidad ${ }^{116}$.

Segundo, la definición no requiere una conexión entre los actos enumerados y un conflicto armado internacional, empero sí requiere un vínculo con algún tipo de conflicto armado, según lo establece el caso Tadic. También, allí se establece que necesita vínculo con un crimen contra la paz o uno de guerra.

Y tercero, la definición el estatuto del Tribunal para la Antigua Yugoslavia especifica que la intención de discriminación es requerida sólo para persecución (Art. $5^{\circ}$, inc. h), y no para otros actos inhumanos considerados como crímenes contra la humanidad (Art. $5^{\circ}$, inc. i) ${ }^{117}$.

114 Tadic fue declarado culpable de crímenes de guerra y crímenes contra la humanidad por la persecución y deportación de civiles musulmanes bosnios de la zona de Prijedor a campos de concentración. Fue condenado a veinte años de prisión.

115 Vid., Sean D. Murphy, "Progress and Jurisprudence of the International Criminal Tribunal for the Former Yugoslavia", American Journal of International Law 93, 1 (enero de 1999), p. 69.

116 Murphy, op. cit., pp. 88-89.

117 McAuliffe de Guzmán, op. cit., p. 351. 
El valor del aporte suministrado por el Art. $5^{\circ}$ queda demostrado cuando el Tribunal acusó a Milosevic de cometer crímenes contra la humanidad en un conflicto armado interno como el de Kosovo (febrero de 1998junio de 1999), cuando provocó una tragedia humanitaria debido a los 750.000 deportados kosovares en Albania y Macedonia principalmente (Art. 5o, inc. d), y 800.000 desplazados en el propio Kosovo dentro de lo que es persecución (inc. h). La solicitud de entrega de Milosevic fue reiterada en octubre del 2000, cuando fue derrocado el dictador, ante el nuevo gobierno de Kostunica por la fiscal Carla Delponte.

\section{(C) CRIMEN DE GENOCIDIO}

El crimen de genocidio está inserto en el Art. $4^{\circ}$ del estatuto. El pár. 2 del citado artículo del estatuto reproduce, casi literalmente, el Art. $2^{\circ} \mathrm{de}$ la Convención para la Prevención y Sanción del Delito de Genocidio de 1948:

"Art. 20.- En la presente Convención, se entiende por genocidio cualquiera de los actos mencionados a continuación, perpetrados con la intención de destruir, total o parcialmente, a un grupo nacional, étnico, racial o religioso, como tal:

a) Matanza de miembros del grupo.

b) Lesión grave a la integridad física o mental de los miembros del grupo.

c) Sometimiento intencional del grupo a condiciones de existencia que hayan de acarrear su destrucción física, total o parcial.

d) Medidas destinadas a impedir los nacimientos en el seno del grupo.

e) Traslado por fuerza de niños del grupo a otro grupo.» ${ }^{18}$

\subsubsection{Jurisdicción personal}

El estatuto señala que el Tribunal tendrá jurisdicción sólo sobre personas naturales (Art. $6^{\circ}$ ), no sobre las personas jurídicas como las organizaciones, etc. El Art. $7^{\circ}$, pár. 1, el estatuto establece la responsabilidad directa del individuo.

118 Convención para la Prevención y la Sanción del Delito de Genocidio de 1948, Art. $2^{\circ}$. 
Además de lo anterior, el estatuto de este tribunal se reafirma en lo establecido por el estatuto de Nüremberg, en cuanto a la no relevancia de la inmunidad soberana de Estados (Art. 70, pár 2).

Asimismo, el estatuto adopta la doctrina de la «responsabilidad de mando (o responsabilidad superior) por crimen por omisión" (Art. 7, pár. 3), recogida de la jurisprudencia post-1945. En el caso Blaskic, el Tribunal rechazó el alegato de la defensa que el penalizar el «descuido de castigar a los perpetradores" era una desarrollo ex post facto del DI Humanitario ${ }^{119}$.

Teniendo todo esto presente, el 28 de mayo de 1999, la fiscal Louise Arbour formuló la primera acusación de un tribunal penal internacional contra un jefe de Estado en funciones, Slobodan Milosevic, por crímenes contra la humanidad, en base a su responsabilidad individual directa y no responsabilidad de mando. Mientras, por otro lado, rechaza el alegato de la «obediencia debida a órdenes superiores» (Art. $7^{\circ}$, pár. 4), aunque se le podrá considerar como atenuante si lo considera el Tribunal. En la sentencia en el caso Erdemovic, el Tribunal señaló que adoptaría la conducta de los tribunales post-1945 que juzgaron a los nazis al no mitigar la condena de altos funcionarios, pero sí la de funcionarios de mando menor, y en consecuencia decidió tomar en cuenta esto al emitir la condena a Erdemovic por crímenes contra la humanidad por ser un soldado que seguía órdenes superiores $^{120}$.

\subsubsection{Jurisdicción territorial y temporal}

El tribunal tendrá jurisdicción (Art. $8^{\circ}$ ) sobre el territorio de la antigua Yugoslavia (el área de lo que fue la República Federativa Socialista de Yugoslavia, disuelta a partir de junio de 1991). A su vez, el tribunal (creado en 1993, en plena Guerra de la Antigua Yugoslavia de 1991-1995) será competente para examinar casos ocurridos desde el 1 enero de 1991, casi seis meses antes del inicio de la Guerra de la Antigua Yugoslavia; al no fijarse plazo de término, su duración será sine die. Este artículo $8^{\circ}$ demostró su validez cuando poco tiempo después estalló la Guerra de Kosovo

119 S.D. Murphy, ibid., p. 72.

120 Murphy, op. cit., p. 93. Erdemovic fue hallado culpable del cargo de crímenes contra la humanidad por su participación en los asesinatos masivos de miles de musulmanes bosnios tras la caída de Srebrenica en julio de 1995. El acusado formaba parte de un pelotón al que se ordenó la ejecución de civiles tomados prisioneros. Vid., Trial Chamber I: Sentencing Judgement, Drazen Erdemovic, Case No. IT-96-22-T, 29 november 1996. 
de 1998-1999. El Consejo de Seguridad determinará la fecha de término, según lo afirmó la fiscalía en marzo de $1998^{121}$.

\subsubsection{Detención del acusado y la Regla 61}

El estatu to no prohíbe expresamente la realización de juicios en ausencia (como sí lo hizo Nüremberg al procesar a Bormann). Empero, sí lo hace implícitamente en los arts. $20^{\circ}-21^{\circ}$, que señalan que un proceso se llevará a cabo una vez que el acusado sea "tomado en custodia» y que uno de los derechos del acusado será el de "hallarse presente en el proceso» ${ }^{122}$.

Empero, la Regla $61^{123}$ de las "Reglas de Procedimiento y Prueba» ${ }^{124}$ (aprobadas por los jueces del tribunal en virtud del Art. $15^{\circ}$ del estatuto) permite un procedimiento (en caso que no pueda localizarse al acusado u obtener su entrega) por el que el Tribunal puede dictar una orden internacional de detención si acepta un informe del fiscal con suficiente evidencia para fundamentar la acusación. Esto es, «una orden dirigida a todos los Estados, no sólo al Estado en donde el acusado se cree esté residiendo» ${ }^{125}$.

En el caso Karadi y Mladi (Prosecutor vs. Karadi and Mladi), el fiscal Richard Goldstone acusó formalmente a Radovan Karadi ("presidente» serbo-bosnio) y a Ratko Mladi («comandante en jefe» del ejército serbobosnio) el 25 de julio de 1995 por crímenes de guerra, genocidio y crímenes contra la humanidad; después, debido a la falta de colaboración de Yugoslavia, el Tribunal emitió el 11 de julio de 1996 una orden internacional de detención conforme a la Regla 61.

\subsubsection{Penas}

El estatuto contempla sólo penas de prisión, excluyéndose la pena capital (Art. 24\%), las que como máximo podrán incluir la cadena perpetua.

121 J. Ferrer Lloret, op. cit., p. 42.

122 Estatuto del Tribunal de la Antigua Yugoslavia, Art. $21^{\circ}$, pár. 4, inc. d.

123 Un trabajo autorizado sobre la Regla 61 y su relevancia ante el Tribunal puede verse, Faiz Patel King, "Public disclosure in Rule 61 proceedings before the International Criminal Tribunal for the Former Yugoslavia", New York University Journal of International Law and Politics 29, 4 (verano de 1997), pp. 523-554.

124 Rules of Procedure and Evidence. IT/32/Rev. 5. 15 June 1995. Sobre la lista de acusados puede verse en internet: (http://www.un.org./icty/BLS/19deten.htm).

125 Sean D. Murphy, "Progress and Jurisprudence of the International Criminal Tribunal for the Former Yugoslavia", American Journal of International Law 93, 1 (enero de $1999)$, p. 58. 


\subsubsection{Evaluación}

Desde su creación, el Tribunal para la Antigua Yugoslavia ha sido minado por la falta total de cooperación de los dirigentes serbios en Belgrado y serbo-bosnios en Pale. Meron le ha calificado de "tigre de papel" y afirma que en contraste con Nüremberg, en donde los aliados tenían un poder policial ilimitado en la realidad (para arrestar y detener a los acusados), el tribunal para la ex-Yugoslavia tiene que depender de la prontitud del Consejo de Seguridad y de la comunidad internacional para ejercer presión para un cumplimiento pleno sobre las partes reluctantes ${ }^{126}$. Es una situación insatisfactoria, pues "la comunidad internacional ha proporcionado al tribunal fuerte apoyo retórico, pero poco apoyo en su aplicación» ${ }^{127}$.

\subsubsection{El Tribunal de Ruanda}

La Resolución No 955 del Consejo de Seguridad del 8 de noviembre de $1994^{128}$, en el caso de la Guerra Civil étnica de Ruanda de abril-julio de 1994 (que incluye el genocidio de los tutsis de abril del mismo año), creó el Tribunal Internacional Penal para Ruanda.

Dicha guerra civil ruandesa estalla cuando el asesinato del presidente Juvenal Habyarimana el 6 de abril de 1994 por obra de extremistas hutus opuestos al Acuerdo de Arusha de agosto de 1993, que establecía un gobierno compartido con el FPR (Frente Patriótico Ruandés) de los tutsis. A horas de cometerse el asesinato, los radicales hutus (militares y milicianos) comenzaron a exterminar a los moderados hutus y la minoría tutsi. ${ }^{129} \mathrm{La}$ guerra interna terminó cuando el FPR llegó al poder a inicios de julio de 1994.

El Consejo de Seguridad declaró que «las personas que hayan instigado o participado en tales actos [violación del $\mathrm{DIH}$ ] son responsables indi-

126 Vid., 'T. Meron, "Answering for War Crimes: Lessons from the Balkans", Foreign Affairs 76, 1 (enero-febrero de 1997), p. 3. Cuando tal presión ha sido poco apoyada, el tribunal se ha hallado de fracaso en fracaso. Lo demuestra el hecho que hasta el momento los máximos criminales de guerra serbo-bosnios, R. Karadzic y R. Mladic, así como S. Milosevic no han sido procesados.

127 Meron, ibid., p. 4.

128 S.C. Res. 955, U.N. Doc. S/RES/955 (8 de noviembre de 1994).

129 Vid., Sheila O'Shea, "Interaction between international criminal tribunal and national legal systems", New York University Journal International Law and Politics 28, 1-2 (invierno de 1996), pp. 402-403. 
vidualmente» $\mathrm{y}$ anunció que «la matanza de los miembros de un grupo étnico con la intención de destruir dicho grupo en su conjunto o en parte constituye un crimen sancionable bajo el Derecho Internacional» ${ }^{130}$.

\section{Jurisdicción}

El Tribunal de Ruanda tiene jurisdicción ratione materiae sobre genocidio (Art. $2^{\circ}$ del estatuto), crímenes contra la humanidad (Art. $3^{\circ}$ del estatuto), y violaciones al Derecho de los Conflictos Armados No Internacionales, i.e., quebrantamientos al artículo $3^{\circ}$ común y al Protocolo II (Art. $4^{\circ}$ del estatuto). Esta última figura constituiría crímenes de guerra cometidos en un conflicto interno ${ }^{131}$.

Tiene jurisdicción ratione temporis y ratione loci para conocer estas violaciones al DIH y también de la Convención contra el Genocidio cometidas entre el 1 de enero y el 31 de diciembre de 1994 en el territorio de Ruanda. Existe jurisdicción concurrente, mas la primaria será la del Tribunal de Ruanda (Art. $8^{\circ}$ ).

Respecto a los individuos que serán procesados por este mecanismo judicial, Ferrer indica que:

«[...] es obvio que el Tribunal Internacional para Ruanda deberá limitarse a ejercer sus funciones en relación a los individuos organizadores o instigadores del genocidio, los más altos dirigentes del Gobierno de Ruanda que cometió el genocidio: desde luego, es impensable que el Tribunal enjuicie a varios miles de individuos. ${ }^{132}$ "

No obstante, estas dificultades el Tribunal emitió sus primeras sentencias. Dictó su primera sentencia en el caso Prosecutor vs. Jean-Paul Akayesu, el 2 de setiembre de 1998, por cometer genocidio y crímenes contra la humanidad; Akayesu era el alcalde de Taba. El aporte de la sentencia emi-

130 Statement by the President of the Security Council, U.N. Doc. S/PRST/1994/21 (1994).

131 El deber de procesar o extraditar impuesto las provisiones sobre graves quebrantamientos de las Convenciones de Ginebra no se extiende al Art. $3^{\circ}$ común. Sin embargo, los Estados tienen la obligación según el Capítulo VII de la Carta para cumplir con las solicitudes de transferencia emitidas por el Tribunal.

$132 \mathrm{~J}$. Ferrer Lloret, «La aplicación de las normas internacionales sobre la responsabilidad penal del individuo: valoración de la práctica más reciente», Revista IIDH, no. 27 (enero-junio 1998), p. 52. 
tida el 2 de setiembre de 1998 por el Tribunal de Ruanda en el caso Akayesu es que constituye la primera condena por un tribunal internacional por el crimen de genocidio.

Asimismo, el primer ministro ruandés Kambanda también fue condenado a cadena perpetua en la sentencia pronunciada en el caso Prosecutor vs. Jean Kambanda, el 4 de setiembre, por cometer genocidio y crímenes contra la humanidad como jefe de gobierno en mayo-junio de $1994^{133}$.

\subsubsection{Críticas a los tribunales ad hoc}

Al margen de las razones que justificaron cada una de estas decisiones, la principal crítica política y jurídica que sobre esta práctica se ha aducido es:

- su carácter de tribunales penales ad hoc,

- creadas con posterioridad a la producción de los hechos que han de ser juzgados (i.e., ex-post facto),

- y limitadas desde el punto de vista de la competencia de los diversos tribunales a conflictos concretos, sin afectar en absoluto otras situaciones comparables ${ }^{134}$.

Desgraciadamente, el siglo XX pasará a la Historia como uno de los períodos en que el sufrimiento causado a humanos por otros humanos ha sido más impresionante.

Empero, el mayor mérito de los tribunales para la Antigua Yugoslavia y de Ruanda estriba en que provocaron el interés en el establecimiento de una corte penal internacional.

\section{LA CORTE PENAL INTERNACIONAL}

\subsection{LA CREACION DE UNA CPI}

3.1.1. Causas que impidieron la creación de un CPI: los Estados

Solamente los Estados poseen la capacidad material de hacer funcionar tribunales penales internacionales, ya sean creados por un tratado multilateral o mediante el Consejo de Seguridad de la ONU.

133 Puede consultarse el sitio Web del Tribunal de Ruanda: www.ictr.org

134 Vid., Antoni Pigrau Solé, "Ante la Conferencia de Roma sobre el establecimiento de un Tribunal Penal Internacional", Revista Naciones Unidas (junio de 1998), pp. 13-14. 
Hasta 1998, por diversas razones los Estados no procedieron al respecto: la extremada reticencia de ellos a ceder áreas que afectan directamente a su soberanía, la preservación de sus intereses nacionales en sus respectivas áreas de influencia, la escasa cohesión ideológica de la sociedad internacional, y la resistencia a asumir costos económicos para el mantenimiento de instituciones internacionales.

Los Estados no habían dado ese paso más que en casos particulares: en el juzgamiento a nacionales de Estados derrotados en una guerra mundial o en casos de violaciones masivas del Derecho Internacional Humanitario en la Post-Guerra Fría.

Como Bledsoe y Boczek señalan:

"Desde que tal Corte [la CPI] necesariamente estaría con potestad de tratar directamente con los individuos más que los intermediarios de los Estados, a ojos de muchos Estados aquella [Corte] representa un paso demasiado radical de los conceptos legales tradicionales en esta etapa en la evolución del Derecho Internacional». ${ }^{135}$

\subsubsection{Superación de los obstáculos: las organizacionesinternacionales}

Sin embargo, también es cierto que algunos factores comienzan a escapar de la dinámica de las relaciones inter-estatales. $Y$ son dos los fundamentales, según anota Pigrau:

Primero, es la dinámica introducida desde las organizaciones internacionales intergubernamentales (OI). Aunque su autonomía política de decisión última es limitada, lo cierto es que la capacidad, ésta sí mucho más autónoma, de las OI de recoger datos, de amplificar la denuncia, de elaborar propuestas, de actuar sobre el terreno, van creando una actividad que proponiendo terminologías, prioridades y ritmos que no coinciden necesariamente con los de los Estados y que éstos no pueden ignorar fácilmente.

Segundo, es el derivado de la acción de las ONG, la sociedad civil global. Lo distintivo del final del siglo $\mathrm{XX}$ no es su existencia, sino su capacidad de influencia, que deriva de la solidez de sus presupuestos ideológicos, del crecimiento de su actividad operativa, de su progresiva profesionalización y de su aptitud para conseguir acumular un apoyo sig-

135 Bledsoe y Boczek, The International Law Dictionary (Santa Bárbara-Oxford: ABC-Clio, 1987), p.75. 
nificativo de distintos sectores de la opinión pública, por encima de las fronteras estatales. ${ }^{136}$

\subsubsection{La Creacion de la CPI: La Conferencia de Roma}

Finalmente, en la Conferencia de Roma, los Estados crean una Corte Penal Internacional no vinculado a un conflicto particular, y es en este contexto en el que hay que valorar la importancia de la Conferencia.

Aunque el tema se discute en el marco de la ONU desde 1948, el texto de referencia para el proyecto de tratado fue adoptado por la CDI el 22 de julio de $1994^{137}$. La Asamblea General discutió la propuesta primero en un Comité Especial y, después, en un Comité Preparatorio.

\section{La conferencia de Roma}

Este Comité Preparatorio finalizó su labor en abril de 1998, cuando adoptó el «Proyecto de Estatuto de la Corte Penal Internacional».

Dicho proyecto fue objeto de debate en la Conferencia de Roma (junio-julio 1998) por los 160 Estados participantes ${ }^{138}$. En la capital italiana finalmente se aprobó por abrumadora mayoría (120 Estados votaron a favor, 7 en contra y 21 se abstuvieron; 12 estuvieron ausentes) el Estatuto de la Corte el 17 de julio de $1998^{139}$.

136 Pigrau, Ibid.

137 Informe de la CDI sobre la labor realizada en su 46o. período de sesiones ( 2 de mayo-22 de julio de 1994), Doc. A/49/10, pp. 23-125.

138 Sobre la lista de los 160 Estados participantes en la "Conferencia diplomática de plenipotenciarios de las Naciones Unidas sobre el establecimiento de una Corte Penal Internacional». Vid., A/CONF. 183/10, español, pp. 10-11. También participaron, como observadores: organizaciones internacionales intergubernamentales (como la Organización de Unidad Africana y la OEA) y no gubernamentales (e.g., Comité Internacional de la Cruz Roja, la INTERPOL, Amnistía Internacional), órganos autónomos de la ONU (p.e., UNICEF, ACNUR, Alto Comisionado de las NU para los DH), y organizaciones nacionales no gubernamentales (como el Colegio de Abogados de los EEUU, el Centro Carter, y la Comisión Colombiana de Juristas). Ibid., pp. 12-18.

139 Conferencia diplomática sobre el establecimiento de una Corte Penal Internacional (Roma, 15 de junio-17 de julio de 1998). Vid., "Informe del Comité Preparatorio sobre el establecimiento de una corte penal internacional", Doc. A/CONF.183/2/Add.1 (del 14 de abril de 1998). También, consúltese el estatuto de la Corte, $c f$. , «Roma Statute of the International Criminal Court», Doc. A/CONF.183/9 (del 17 de julio de 1998); 
Este estatuto entrará en vigor después que 60 Estados firmantes entreguen su instrumento de ratificación (Art. 126 del Estatuto).

El comité citado rechazó postreras enmiendas de India y EEUU, que no votaron en favor de la aprobación del estatuto. Cuba y México señalaron que mantendrían sus reservas. México, que se opone a "ciertos puntos que según ellos afectan la soberanía de su país", no descarta la posibilidad de firmarlo después de presentar reservas. El acuerdo propone un compromiso entre los partidarios y los adversarios de una Corte fuerte y no contempla las condiciones planteadas por EEUU ${ }^{140}$. Según declaró William Pace, coordinador de las 260 ONG que participaron como observadores en los debates, «este tratado no es una victoria pero hay que reconocer que representa una derrota para las grandes potencias» ${ }^{141}$.

\section{Estructura del estatuto}

El estatuto de la CPI no siguió el modelo del estatuto de la Corte Internacional de Justicia (CIJ) por una razón importante, y era la relacionada con la ratificación de los Estados. Esto era debido a que los Estados estaban más interesados con la jurisdicción y la aplicación de la jurisdicción de la CPI (y por tanto cuándo estarían sujetos a su competencia), que con otros tópicos.

En consecuencia, la cuestión jurisdiccional y su ejercicio (Parte II: Jurisdicción, Admisibilidad y el Derecho Aplicable, arts. $5^{\circ}-2^{\circ}$ ) es la central y precede a todas las demás en el estatuto de la $\mathrm{CPI}^{142}$. Debemos recordar que el texto de la Parte II fue negociado hasta el último dia de la conferencia, en vísperas de la votación para aprobar el estatuto.

<www.un.org/icc>; reimpreso en International Legal Materials vol. 37 (1998).

$140 \mathrm{Vid}$., «Aprueban estatuto de tribunal que juzgará a criminales de guerra", Diario $E l$ Comercio, 18 de julio de 1998, p. B-6.

$141 O p$. cit. Las ONG, en su mayoría de DH, que en representación de la sociedad civil fue un grupo permanente de presión, admitieron que estaban divididas respecto al proyecto. El portavoz de América Latina, Gustavo Gallón, de la Comisión Colombiana de Juristas, definió el estatuto como «un embrión que dará sus frutos en muchos años y quizás serán nuestros nietos los que estarán menos desprotegidos».

142 Esta estructura del estatuto, que privilegia la cuestión de la jurisdicción, fue diseñada por el Comité Preparatorio en enero de 1998 y «ni el Comité Preparatorio ni la Conferencia de Roma reconsideraron la estructura del estatuto». Vid., Mahnoush H. Arsanjani, "The Rome Statute of the International Criminal Court", American Journal of International Law 93, 1 (enero de 1999), p. 24. 


\section{Principios angulares del estatuto de la CPI}

\section{Dos principios presiden el fundamento del estatuto.}

Primero, el principio de complementariedad, el cual establece que la corte ejercerá jurisdicción sólo cuando los sistemas jurídicos internos no puedan o no deseen ejercerla. Por tanto, en caso de jurisdicción concurrente entre jurisdicción nacional o de la Corte, la jurisdicción primaria será la nacional. Esto constituye una diferencia relevante con los dos tribunales ad hoc ${ }^{143}$ de los albores de la Post-Guerra Fría.

Segundo, el principio de especialidad, según el cual el estatuto está diseñado para tratar sólo con los más graves crímenes que afecten los fundamentos de la comunidad internacional. Así, no examinará casos que los Estados pueden tratar adecuadamente y dedicará toda su atención a estos pocos pero relevantes tópicos ${ }^{144}$.

\subsection{Personalidad Juridica de la CPI}

La Corte Penal Internacional será un sujeto de Derecho Internacional. Dispondrá de personalidad jurídica internacional y será organización internacional intergubernamental, esto se infiere de su capacidad para vincularse mediante acuerdo negociado bilateral con la ONU (Art. $2^{\circ}$ ).

La capacidad para concluir tratados y para relacionarse con otros sujetos de DI, demuestra que poseerá capacidad de obrar y por tanto de personalidad jurídica ante el DI. Hecho que es ratificado por el estatuto de la $\mathrm{CPI}$, que señala expresamente que utendrá personalidad jurídica internacional» (Art. 4º, pár. 1).

Asimismo, la CPI podrá disponer de personalidad jurídica en el Derecho interno de un Estado parte y de cualquier otro Estado (Art. $4^{\circ}$, pár. 2).

$143 C f$., Estatuto para la Antigua Yugoslavia, Art. 9º y el Estatuto para Ruanda, Art. $8^{\circ}$, los que indican que en caso de jurisdicción concurrente, los tribunales internacionales tendrán la primaria.

144 Hay un tercer principio que añade Arsanjani. Señala que el estatuto deberá en lo posible permanecer dentro del DI consuetudinario. Esto era para lograr mayor respaldo al estatuto, pues la definición de los crímenes internacionales se hace en base al D consuetudinario. Las normas que definen los crimen han recibido apoyo de los Estados negociadores. Vid., M. Arsanjani, "The Rome Statute of the International Criminal Court", American Journal of International Law 93, 1 (enero de 1999), p. 25. 


\subsection{Jurisdiccion de la CPI}

El objetivo de esta CPI es de juzgar a los acusados de los crímenes internacionales más graves, a su vez será una Corte permanente y que tiene un carácter complementario de las jurisdicciones penales nacionales. Fueron varias las cuestiones principales respecto a su jurisdicción que fueron objeto de acalorada controversia.

\subsubsection{Jurisdiccion Ratione Materiae: Tipologia de Crimenes dentro de la Jurisdiccion de la Corte}

La primera cuestión controvertida en los debates se refería al tipología de crímenes respecto de los que la CPI es competente. Así, mientras existía un amplio acuerdo en torno al crimen de genocidio, hubo bastante debate sobre la definición de los distintos crímenes de agresión, de guerra y contra la humanidad. Por otro lado, hubo propuestas para incluir los casos de terrorismo, de crímenes contra la ONU y su personal, y el tráfico ilícito de drogas ${ }^{145}$.

La CPI tiene jurisdicción según su estatuto respecto a los siguientes crímenes: crimen de agresión, crímenes de guerra, crímenes contra la humanidad y crimen de genocidio.

\subsubsection{Crimen de agresión}

Hubo muchas dificultades para la definición de este crimen. Mientras, la mayoría de los Estados en la conferencia prefería una definición que no sea susceptible de revisión por el Consejo de Seguridad, otros como los miembros permanentes proponían que la CPI tuviera competencia sólo después que el Consejo determinara una agresión.

El estatuto (Art. $5^{\circ}$, pár. 2) refleja un compromiso y señala que la CPI ejercerá jurisdicción sobre el crimen de agresión cuando sea adoptada una

145 La oposición para incluir estos últimos delitos estaba basada en el hecho que la naturaleza de la investigación de los crímenes del tráfico de drogas y terrorismo, que requiere planeamiento de largo plazo, infiltración en las organizaciones involucradas, la necesidad de dar inmunidad a algunos individuos involucrados, lo hacen más adecuados a la jurisdicción nacional. Vid., Arsanjani, op. cit., p. 29. Estos crímenes serán objeto de estudio en una futura Conferencia de Revisión. Vid. Acta Final de la Conferencia Diplomática de Plenipotenciarios de las Naciones Unidas sobre el Establecimiento de una Corte Penal Internacional, A/CONF. $183 / 10^{*}$, p. 8. 
disposición que defina el crimen y establezca las condiciones bajo las cuales la Corte ejercerá su jurisdicción y que sea "compatible con las disposiciones pertinentes de la Carta de las Naciones Unidas». Esta cita tiene la intención de tener en cuenta los intereses de los miembros permanentes del Consejo de Seguridad y que el estatuto de la Corte no sea utilizado para enmendar la Carta al limitar la competencia del Consejo para determinar los actos de agresión.

Sin embargo, podríamos señalar grosso modo que constituiría una consecuencia de la violación del principio de prohibición del uso de la fuerza consagrado en la Carta de la ONU ${ }^{146}$.

\subsubsection{Crimen de genocidio}

Este fue el único crimen que recibió un unánime respaldo. Reproduce el estatuto de la CPI (Art. 6\%), al igual que lo hiciera el estatuto del Tribunal de la Antigua Yugoslavia, el Art. $2^{\circ}$ de la Convención sobre Genocidio de 1948, reemplazando igualmente la palabra "Convención» por la palabra "estatuto".

Considera como tal a las medidas destinadas al exterminio total o parcial de un grupo étnico, racial, nacional o religioso.

\subsubsection{Crímenes contra la humanidad}

Su definición en el estatuto fue fruto de largos debates respectivos.

\section{Evolución del concepto}

La acepción dada a los crímenes contra la humanidad ha evolucionado desde el Tribunal de Nüremberg.

Inicialmente, este crimen era enfocado como una violación grave del Derecho Humanitario (lo que era correcto según la intención de los redactores de la Cláusula Martens sobre las «leyes de la humanidad»). Consecuentemente, los aliados optaron por no mantener la acusación del genocidio armenio después de la Primera Guerra Mundial.

El estatuto del Tribunal de Nüremberg incluyó al crimen contra la humanidad, si bien constituía claramente un desarrollo innovador, era considerado por los aliados como firmemente basado y con raíces en el

146 Carta de la ONU, art. 2, pár. 4., que establece la prohibición del uso o de la amenaza del uso de la fuerza. 
DI consuetudinario ${ }^{147}$ y se consideró como una violación de los principios generales de Derecho (en especial de los Derechos Penales internos) de las naciones civilizadas ${ }^{148}$; por tanto, a su juicio, no violaba el principio de legalidad. Eran crímenes cometidos contra las personas sin tener en cuenta su nacionalidad y que no constituían violaciones a las leyes de guerra.

De esta manera, si bien se podía castigar persecuciones racistas y políticas, debían estar vinculadas con los otros dos crímenes ${ }^{149}$ bajo jurisdicción del Tribunal, crímenes contra la paz y de guerra; vinculación con un conflicto armado (i.e., la Segunda Guerra Mundial de 1939-1945).

Así, actos inhumanos como persecución y genocidio que no constituyeran crímenes de guerra, que se realizaron antes del inicio del conflicto (antes de 1939) no eran crímenes contra la humanidad para el Tribunal, y los que fueron cometidos después del inicio, sí constituían tales crímenes.

Pese a su vinculación con un conflicto armado, el hecho de sancionar el Tribunal de Nüremberg crímenes graves de un régimen contra sus propios nacionales (p.e. genocidio) ya era un avance importante. El siguiente paso debía ser cortar dicho vínculo.

Casi inmediatamente, la Ley No 10 del Consejo de Control Interaliado de diciembre de 1945 proporcionó un aporte relevante en la noción de los crímenes contra la humanidad al no vincularlos con una guerra ${ }^{150}$.

147 Pues, los aliados lo percibían como una laguna jurídica en el DI positivo.

148 Los crímenes de asesinato, esclavitud, genocidio están castigados por el Derecho in terno de los Estados y no pierden su carácter criminal por ser cometidos a escala masiva. Vid., Margaret McAuliffe deGuzman, «The Road from Rome: The Developing Law of Crimes against Humanity", Human Rights Quarterly 22 (mayo del 2000): 344.

149 «El Art. 6, inc. C, del estatuto del Tribunal de Nüremberg que define los crímenes contra la humanidad señala que son aquellos: "cometidos contra cualquier población civil antes o durante la guerra [...] en conexión con cualquier crimen de la jurisdicción del Tribunal». Como puede observarse si bien teóricamente permitía juzgar estos crímenes antes de la guerra, en la práctica no lo hizo pues requería la conexión con los otros crímenes. En base a dicho fundamento, sólo Streicher fue hallado condenado por crímenes contra la humanidad cometidos antes de 1939.

150 McAuliffe de Guzmán, op. cit., p. 348. Si bien la Ley No 10 omite el nexo con la guerra, el preámbulo de esta ley contiene un vínculo jurisdiccional con el Estatuto de Nüremberg (que, como sabemos, incluye el nexo con la guerra). Por esta razón, la jurisprudencia de los tribunales de la Ley No 10 está dividida en que si la comisión de los crímenes contra la humanidad deben estar en conexión con la guerra (casos Einsatzgruppen y de Justicia) o no (caso Flick). No obstante, la parte dispositiva de la Ley No 10 omite el nexo 
Pese al avance prometedor que significó la Ley No 10 Interaliada, hubo después un retroceso. Así, la Resolución 95 (I) de la Asamblea General de la ONU del 11 de diciembre de 1946 «Los Principios de Nüremberg» volvió a vincular los crímenes contra la humanidad con el estado de conflicto armado. Como se ha visto antes, también el estatuto del Tribunal de la Antigua Yugoslavia mantiene dicha vinculación ${ }^{151}$ (aunque reconoce su comisión incluso en un conflicto armado interno).

Sin embargo, el estatuto de la CPI, con su opinión autorizada, dirime el problema y alcanza su contribución al DI al desvincular tales crímenes de un conflicto armado.

\section{La vinculación con un conflicto armado}

En Roma, los Estados decidieron no insertar un dispositivo limitado sobre este crimen similar al modelo del estatuto del Tribunal de la Antigua Yugoslavia. Así, optaron por no vincular el crimen contra la humanidad con un conflicto armado sino "como parte de un ataque generalizado o sistemático contra una población civil» ${ }^{152}$. Aquí se incluyen actos o ataques sistemáticos contra cualquier población civil, como: asesinato, deportación, esclavitud, persecución, desaparición forzada de personas o el apartheid (Arr. $7^{\circ}$ ).

Dicho ataque debe implicar múltiples actos contra la población «de conformidad con la política de un Estado o de una organización ${ }^{153}$ in-

con la guerra (a diferencia del estatuto de Nüremberg cuya parte dispositiva sí la establece), y esto es el aporte.

151 Desde 1945, se ha ido definiendo la naturaleza de los crímenes contra la humanidad en diversas normas de DI. Entre ellas podemos citar: Los Principios de DI Reconocidos por el Estatuto del Tribunal de Nüremberg de 1946 (Resolución 95-I de la Asamblea General de la ONU); la Convención sobre la Prevención y Castigo del Crimen de Genocidio de 1948; Convención Internacional sobre la Eliminación de Todas las Formas de Discriminación Racial de 1966; la Convención sobre la Imprescriptibilidad de los Crímenes de Guerra y Crímenes contra la Humanidad de 1968; la Convención Internacional para la Supresión y Castigo del Crimen del Apartheid de 1973; los Principios de Cooperación Internacional en la Detección, Arresto, Extradición y Castigo de Personas Culpables de Crímenes de Guerra y Crímenes contra la Humanidad de 1973; la Convención Internacional contra la Toma de Rehenes de 1979; y la Convención contra la Tortura y otros Tratos o Castigos Crueles, Inhumanos o Degradantes de 1984.

152 Art. $7^{\circ}$, pár. 1.

153 Art. $7^{\circ}$, pár. 2 , inc. a. 
cluso en ausencia de conflicto armado. El término «organización» fue diseñado para incluir grupos terroristas y grupos insurgentes si fuera el caso.

A diferencia del estatuto del Tribunal ad hoc citado que sólo enumera los actos constitutivos de este crimen ${ }^{154}$, el estatuto de la CPI también pasa a definirlos ${ }^{155}$. Por ejemplo, la definición de violencia sexual es más amplia ${ }^{156}$ que la dada por el Tribunal ad hoc ${ }^{157}$. El estatuto de la CPI agrega dos figuras adicionales: la desaparición forzada de personas y el apartheid. En relación con el apartheid, si bien es un término y sistema creados por la Sudáfrica racista, éste ha pasado a representar todo sistema de discriminación racial o tendiente a la supremacía étnica, como el que fue impuesto por Milosevic en Kosovo y su limpieza étnica (que no era sino un eufemismo por el genocidio).

Al igual que con el genocidio, los crímenes contra la humanidad representan una consecuencia de la violación grave de los Derechos Huma$\operatorname{nos}^{158}$.

\subsubsection{Crimenes de guerra}

El estatuto de la CPI utiliza como sinónimos los términos «Derecho Internacional de los Conflictos Armados» y 174Derecho Internacional Humanitario". Art 21 : "principios establecidos del derecho internacional de los conflictos armados». Art. $8^{\circ}$ : «leyes y usos aplicables en los conflictos armados».

Este tema fue muy controvertido en las negociaciones. Surgieron dificultades especiales respecto a los conflictos armados internos, las armas nucleares y las nuevas armas.

Para evitar una dispersión inútil y desproporcionada de la atención de la CPI, se decidió que la Corte tendría especial ("particular») jurisdicción sobre los crímenes más graves (Art. $8^{\circ}$, pár. 1 ), esto colegía que no todo crimen de guerra sería automáticamente objeto de examen de esta instan-

154 Estatuto del Tribunal de la Antigua Yugoslavia, Art. $5^{\circ}$.

155 Estatuto de la CPI, Art. $7^{\circ}$, pár. 2.

156 Art. $7^{\circ}$, pár. 1 , inc. g.

157 Estatuto del Tribunal de la Antigua Yugoslavia, Art. 5º, inc. g (violación) e inc. i (otros actos inhumanos).

158 Declaración Universal de los Derechos Humanos del 10 de diciembre de 1948. También, inter alia, la Convención Europea para la Protección de los DH de 1950, la Convención Internacional sobre D Civiles y Políticos de 1966. 
cia judicial ${ }^{159}$, sin embargo no estaba impedida de conocer crímenes de guerra cometidos en escala limitada o a nivel individual.

\section{Conflictos internacionales e internos}

El estatuto considera como crímenes de guerra a las violaciones de las Convenciones de Ginebra de 1949 en especial (Art. 8º pár. 2, inc. a), y del Derecho de los Conflictos Armados Internacionales (o sus términos equivalentes «Derecho de Guerra», «leyes y usos de la guerra» o «Derecho Internacional Humanitario") en general (Art. $8^{\circ}$, pár. 2 , inc. b).

Una notable innovación es que incluye a las violaciones al Art. $3^{\circ} \mathrm{co}-$ mún de las Convenciones de Ginebra de 1949 (Art. 8º pár. 2, inc. c) en especial ${ }^{160}$, y al Derecho de los Conflictos Armados No Internacionales en general (Art. $8^{\circ}$, pár. 2 , inc. e). Concordante con el Derecho Internacional de los Conflictos Armados No Internacional, cuyas normas strictu sensu no se aplican a situaciones de tensiones y disturbios internos, como motines y actos esporádicos de violencia, la CPI tampoco ejercerá competencia sobre dichos actos (Art. $8^{\circ}$, pár. 2 , inc. d).

Para tranquilizar a los Estados, el estatuto (Art. $8^{\circ}$, pár. 3) reafirma la validez del principio de no intervención en asuntos internos de los Estados.

\section{Crímenes contra las fuerzas de la ONU y bienes culturales}

Respecto a los crímenes contra las fuerzas de la ONU (sea en operaciones de mantenimiento de la paz ${ }^{161}$ o de asistencia humanitaria), España propuso (y recibió respaldo) que se le incluyera dentro de la categoría mayor de crímenes de guerra. Así, figura como crimen sea en un conflicto armado internacional ${ }^{162}$ o interno ${ }^{163}$. Aunque no cita ataques contra otros

159 Art. $8^{\circ}$, pár. 1 , del estatuto señala que «La Corte tendrá competencia respecto de los crímenes de guerra en particular cuando se cometan como parte de un plan [...] o como parte de la comisión en gran escala de tales crímenes".

160 Mas, no incluye disturbios y tensiones internas tales como actos aislados de violencia y otros (Art. 8, pár. 2, inc. d).

161 Las operaciones de mantenimiento de la paz se dividen en dos clases: misiones de observadores y fuerzas de mantenimiento de la paz.

162 Art. $8^{\circ}$, pár. 2 , inc. b, apartado iii.

163 Art. $8^{\circ}$, pár. 2 , inc. e, apartado iii. 
fuerzas internacionales de otras organizaciones regionales, se podría aplicar este dispositivo por analogía.

También este dispositivo incluye, como se infiere, a la protección de la propiedad cultural y educativa ${ }^{164}$ según lo prescribe la IV Convención de La Haya de 1907 (Art. $27^{\circ}$ del Reglamento ${ }^{165}$ ), la Convención para la Protección de los Bienes Culturales en caso de Conflicto Armado de 1954 y el Protocolo I (Arts. $53^{\circ}$ y $85^{\circ}$, pár. 4).

\section{Crímenes de género e infantiles}

Asimismo, se contemplan dentro de los crímenes de guerra, los de violencia sexual. Habida cuenta de la trágica experiencia de embarazos forzados y violaciones sexuales masivas y planificadas en las guerras de Bosnia y Kosovo perpetradas por la ignominiosa política de limpieza étnica serbia en un burdo intento por alterar las fronteras demográficas, gracias al impulso de las ONG (organizaciones no gubernamentales), se aseguró la inclusión de este dispositivo en el estatuto ${ }^{166}$.

En realidad, los tribunales ad hoc ${ }^{167}$ ya habían emitido ciertas decisiones principalmente en los casos Akayesu, Celebici, y Furundzija que involucraban muchos crímenes cometidos casi exclusivamente contra mujeres y niñas. ${ }^{168}$ La relevancia de la sentencia en el caso Akayesu es histórica pues afirma decisivamente el vínculo profundo de la violencia sexual con el genocidio de Ruanda. Por añadidura, la jurisprudencia extraída de los casos Furundzija y Celebici tendrán un impacto significativo en el trato de víctimas de violación y otras víctimas de tortura y otros crímenes. Al

164 Art. $8^{\circ}$, pár. 2 , inc. b (apart. ix) y e (apart. iv).

165 Art. $27^{\circ}$ del Reglamento anexo a la IV Convención: «En los sitios y bombardeos se adoptarán todas las precauciones necesarias para respetar, en cuanto sea posible, los edificios dedicados al culto, al arte, a la ciencia y a la beneficencia, los monumentos históricos, los hospitales y las clínicas de enfermos y heridos, siempre que al mismo tiempo no se utilicen para fines militares.»

166 Art. $8^{\circ}$, pár. 2, incs. b (apartado vi) y e (apart. xxii) del estatuto de la CPI.

167 A diferencia de los tribunales de Nüremberg y de Tokio que ignoraron los crímenes de género, los tribunales de la Antigua Yugoslavia y de Ruanda superaron los obstáculos y afrontaron estos crímenes.

168 Kelly D. Askin, "Sexual violence in decisions and indictments of the Yugoslav and Rwandan tribunals: current status", American Journal of International Law 93, 1 (enero 1999): 98. 
respecto, las fiscalías dieron pasos significativos para formular acusaciones basadas en crímenes de género.

El estatuto considera como un crimen de guerra, el reclutamiento de niños menores de quince años de edad para utilizarlos en las hostilidades sea en conflictos armados internos o internacionales ${ }^{169}$, se les consideraba como transgresiones flagrantes a la Convención de los Derechos del Niño de $1989^{170}$, y a los Protocolos I I71 y II ${ }^{172}$ de 1977.

\section{Armas nucleares y nuevas armas}

Respecto a la cuestión de la legitimidad del uso de las armas nucleares, el estatuto optó (para lograr respaldo de las potencias nucleares y que son miembros permanentes del Consejo de Seguridad) por no incluir referencia alguna a este tipo de armas ${ }^{173}$.

Sobre futuras armas cuyo uso pudiese constituir violación de las normas humanitarias y, por ende, crímenes de guerra, el tenor del estatuto (Art. $8^{\circ}$, pár. 2 , inc. b, apart. $\mathrm{xx}$ ) establece tres precondiciones: primero, que represente una violación del principio de prohibición de males superfluos; segundo, que tales armas sean objeto de una proscripción generalizada; y tercero, que tales armas deberán estar incluidas en un anexo futuro que se adjuntará al estatuto (lo que deja la posibilidad de incluir armas nucleares) ${ }^{174}$.

\subsubsection{Elementos del crimen}

En los debates, se planteó la inclusión de elementos definitorios del crimen de guerra, ampliado después a todos los demás crímenes. Para EEUU, en aras del principio de legalidad que exigía que los crímenes estuvieran lo suficientemente definidos. Empero, la mayoría de los Estados se opuso, porque pensaban se dilataría la aprobación del estatuto y

169 Art. $8^{\circ}$, pár. 2 , inc. b (apart. xxvi) y e (apart. vii).

170 Art. $28^{\circ}$.

171 Protocolo I, Art. $77^{\circ}$, pár. 2.

172 Protocolo II, pár. 4 , inc. $3 \mathrm{c}$.

173 En relación con la legitimidad de las armas nucleares, vid., Pablo Fernández S., La licitud del uso de las armas nucleares en los conflictos armados (Sevilla: Universidad de Huelva, 1997).

174 Empero, tal proscripción será obligatoria para los Estados que ratificaron la enmienda a aquel anexo. 
porque en todo caso consideraban era superfluo desde que todos los elementos definitorios de los crímenes ya estaban incluidos en la Parte II (arts. $5^{\circ}-8^{\circ}$, en la definición de los crímenes) y en la Parte III (Principios Generales de Derecho penal).

Como compromiso, el estatuto de la CPI estableció que se incluirían los elementos definitorios del crimen en el art. 9, pero a condición que su elaboración y adopción por la Asamblea General de Estados partes se haga separadamente de la aprobación y entrada en vigor del estatuto ${ }^{175}$.

Como podemos observar se amplía la tipología de Nüremberg que incluía la triple división clásica de crímenes: contra la paz, de guerra, y contra la humanidad. En realidad, el crimen de genocidio, contemplado ahora de forma separada por el estatuto de la CPI, estaba antes incluido en Nüremberg en la categoría mayor de crímenes contra la humanidad.

\subsubsection{JURISDICCION RATIONE PERSONAE: RESPONSABILIDAD PENAL INDIVIDUAL}

\subsubsection{Responsabilidad individual directa}

La CPI tendrá jurisdicción sobre individuos que cometan crímenes comprendidos dentro de su estatuto (Art. 25\%). Aquellos incurrirán en responsabilidad penal individual directa.

La Corte sólo tendrán competencia con respecto a personas naturales, se descarta así el enjuiciamiento de personas jurídicas o instituciones, como ocurriera en Nüremberg al procesar, inter alia, al gobierno del Reich o las SS ${ }^{176}$.

Sin embargo, la responsabilidad penal del individuo no afectará la responsabilidad del Estado (Art. 25०, pár. 4); esto queda demostrado con la demanda de Bosnia contra Serbia en 1993 ante la CIJ por incumplimiento de la Convención sobre Sanción del Genocidio de 1948, lo que no era óbice para la sanción de los criminales de guerra ante el Tribunal para la Antigua Yugoslavia (desde 1993). Como señala Ambos, se reconoce el principio de responsabilidad penal individual, y agrega:

175 Como consecuencia de la decisión de la Conferencia de Roma, los proyectos de textos de los Elementos del Crimen y de las Reglas de Procedimiento fueron preparados por la Comisión Preparatoria y presentados en junio del 2000.

176 La pertenencia a una entidad declarada como organización criminal puede ser injusto en ocasiones, sobretodo con aquellos reclutados no voluntariamente. 
"La responsabilidad penal de las personas jurídicas [cursiva añadida por Ambos] fue finalmente rechazada - a pesar de la limitación a los órganos de dirección de empresas privadas - por las razones siguientes: su reconocimiento se hubiera apartado de la responsabilidad individual del autor así como hubiera puesto, y en consecuencia exigido demasiado, a la Corte frente a problemas de pruebas insalvables; por lo demás, la responsabilidad de las personas jurídicas ni está universalmente reconocida ni existen reglas de imputación consensuadas ${ }^{177}$."

También un individuo incurrirá en responsabilidad penal individual si contribuye de algún modo a la comisión de un crimen o crímenes (Art. $25^{\circ}$, pár. 3 , inc. d), lo que puede incluir otras formas de participación, incluyendo la conspiración ${ }^{178}$, como fue, por ejemplo, el caso de los nazis ante el tribunal de Nüremberg (por planificar guerras de agresión).

La responsabilidad se extenderá también a la incitación pública y directa en casos de genocidio (Art. $25^{\circ}$, pár. 3, inc. e). El caso más relevante sobre esta figura es el de Julius Streicher, director de la revista racista y antisemita Der Stürmer, que preconizaba públicamente el exterminio de los judíos, razón por la cual fue hallado culpable de cometer crímenes contra la humanidad por el Tribunal de Nüremberg ${ }^{179}$.

\subsubsection{Irrelevancia de la Inmunidad de Estados}

Para la Corte no existe relevancia del principio de inmunidad de Estados extranjeros (Art. 270). El concepto de responsabilidad penal individual, y en consecuencia, de la irrelevancia de la capacidad oficial para eximirse de responsabilidad individual, ya había sido afirmado en la sentencia del Tribunal de Nüremberg del 30 de setiembre de 1946:

177 Kai Ambos, «Sobre el fundamento jurídico de la Corte Penal Internacional: Un análisis del Estatuto de Roma", Revista de Derecho Penaly Criminología, 5 (2000): 141.

$178 \mathrm{La}$ conspiración es un concepto que no existe como tal en los sistemas del derecho civil, mas sí en los del common law. Fue tomado del Art. $3^{\circ}$, pár. 3, inc. c, de la Convención Internacional para la Supresión de Atentados Terroristas de 1998.

179 Streicher destacó por su racismo, hasta convertir su nombre en símbolo del mismo, su revista Der Stürmer (“El Asaltante») era su órgano de propaganda y de incitación al odio racial. Fue condenado a muerte por el Tribunal Militar Internacional de Nüremberg, acusado de crímenes contra la humanidad. Vid., C. Zentner (ed.), El Tercer Reich (Buenos Aires: ANESA-Noguer), p. 318. 
«... El principio de derecho internacional que, en ciertas circunstancias, protege a los representantes de un Estado, no puede aplicarse a los actos que tal derecho condena como criminales. Los autores de dichos actos no pueden resguardarse tras sus cargos oficiales para librarse de la sanción de los juicios apropiados... Quien viola las leyes de la guerra no puede lograr la inmunidad por el sólo hecho de actuar en obediencia a la autoridad del Estado, cuando el Estado, al autorizar su actuación, sobrepasa su competencia según el derecho internacional ...." ${ }^{180}$

\subsubsection{Responsabilidad de mando por crimen por omisión}

Asimismo, el principio de la «responsabilidad de mando (o responsabilidad superior) penal por crimen por omisión" de los comandantes militares, establecido e ilustrado por el caso Yamashita, quedó confirmada por el estatuto (Art. 28). La acusación del tribunal militar americano de Manila había establecido que el general Yamashita, en las Filipinas (entre octubre de 1944 y setiembre de 1945):

«... como comandante de las fuerzas armadas del Japón en guerra con los EUA y sus aliados, ilegalmente descuidó y fracasó en ejercer su deber como comandante para controlar las operaciones de los miembros de su mando, permitiéndoles cometer atrocidades brutales y otros grandes crímenes contra personas de los EEUU y de sus aliados y dependencias, particularmente Filipinas; y él...por tanto violó las leyes de la guerra.» ${ }^{181}$

La responsabilidad de mando reconoce sus raíces en las Convenciones de La Haya de $1907^{182}$, que a juicio de Bantekas «creó deberes de mando afirmativas en relación con la conducta de las personas subordinadas» ${ }^{183}$.

180 Vid., Oda, op. cit., p. 493.

181 Vid., B.V.A. Röling, "The Law of War and the National Jurisdiction since 1945", Recueil des Cours de l'Academie de Droit International, t. 100-II (1960), p. 378.

182 IV Convención de La Haya de 1907, art. 43 del Reglamento anexo. X Convención de La Haya de 1907, Art. $19^{\circ}$ del Reglamento anexo.

183 Bantekas, director del Centro de Derecho Internacional de la Universidad de Westminster, preparó un ensayo relevante sobre el Derecho de la Responsabilidad de Mando. Vid., Ilias Bantekas, "The Contemporary Law of Superior Responsibility", American Journal of International Law 93, 3 (julio de 1999), pp. 593-595. 
Si bien los tribunales internacionales de Nüremberg y de Tokio sólo trataron con la responsabilidad directa (no contenían normas expresas respectivas), los procesos americanos (contra generales japoneses) subsiguientes suministraron un amplio precedente jurídico en apoyo de este principio y diseñaron su contenido, entre ellos los casos Yamashita y Homma. En cambio, en el proceso de Nüremberg contra los jefes alemanes, no se adoptó esta responsabilidad. Röling nos recuerda que durante el juicio contra el almirante Doenitz ${ }^{184}$, el Tribunal estableció el hecho que si bien después de torpedear buques los submarinos alemanes mataban a los supervivientes, Doenitz no fue hallado culpable sobre este cargo por razón que la evidencia no establecía con la debida certeza que Doenitz ordenó deliberadamente la muerte de los náufragos supervivientes». ${ }^{185}$ Subsiguientes tribunales aliados enfocaron la responsabilidad de mando por aplicar órdenes ilegales al evaluar la capacidad del acusado o su oposición a dichas órdenes. En el caso del Alto Mando ${ }^{186}$ los acusados fueron procesados por aplicar órdenes ilegales de Hitler para ejecutar civiles opositores y comandos; en el caso de los Rehenes ${ }^{187}$ los acusados fueron condenados por aceptar o permitir la ejecución de rehenes civiles en los Balcanes; en el caso de los Ministerios ${ }^{188}$ examinó la capacidad de los acusados, funcionarios del gobierno del Reich, para oponerse al exterminio de los judíos.

Pese a la amplia jurisprudencia extraída de los procesos aliados post1945, ninguna disposición expresa sobre la responsabilidad de mando se incluyó en las Convenciones de Ginebra de 1949. Su consecuencia fue el declive de la relevancia de la responsabilidad de mando hasta unas décadas después. Si bien el Protocolo I de $1977^{189}$ reinsertó este tipo de responsabilidad, al igual que los estatutos de los tribunales de la Antigua Yugosla-

184 El Gran-Almirante Karl Doenitz, fue comandante de la flota submarina alemana durante la Segunda Guerra Mundial, en 1943 fue nombrado comandante en jefe de la Marina de Guerra alemana. Fue designado Presidente del Reich a la muerte de Hitler el 30 de abril de 1945 .

185 «La razón era que existían tantas órdenes criminales alemanas que la fiscalía no necesitaba remarcar la responsabilidad por omisiones. En Japón, generalmente las órdenes eran correctas, pero la práctica en el campo era aborrecible». Cf., Bert V.A. Röling, "The Law of War and the National Jurisdiction since 1945", Recueil des Cours de l'Academie de Droit International, t. 100-II (1960), p. 378-379.

186 United States vs. Von Leeb.

187 United States vs. List et al.

188 United States vs. Von Weizsaecker.

189 Arts. $86^{\circ}$ y $87^{\circ}$. 
via y de Ruanda, el verdadero avance vino cuando este principio fue aplicado en casos reales.

Hasta el caso Celebici, la jurisprudencia internacional desde los juicios aliados post-1945 sólo había juzgado casos por responsabilidad directa (más fácil de condenar que los de responsabilidad de mando). Los casos Blaskic y Celebici ${ }^{190}$ influenciaron decisivamente finalmente los debates preparatorios y así se incluyó el Art. $28^{\circ}$ del estatuto de la CPI, consolidándose definitivamente ante el Derecho Penal Internacional el principio de la responsabilidad de mando por crimen de omisión.

\subsubsection{Irrelevancia de la obediencia debida a órdenes superiores}

El estatuto se reafirma en lo establecido por la jurisprudencia de Nüremberg, aceptada por los Tribunales de la Antigua Yugoslavia y Ruanda, respecto a que el alegato de la «obediencia debida a órdenes superiores» no eximirán al individuo de responsabilidad penal por cometer crímenes (Art. 330 $)^{191}$.

Empero, puede eximirse o mitigarse la responsabilidad si: la persona estaba bajo la obligación legal de cumplir tales órdenes, tales subordinados no sabían que dicha orden era ilegal, y si la orden no era manifiestamente ilícita (Art. 33o, pár. 1 del Estatuto).

\subsubsection{Causas para la exención o atenuación de la pena}

Los menores de 18 años de edad estarán excluidos (Art. 26\%) de la competencia de la Corte.

Se excluye la responsabilidad del individuo en determinadas circunstancias (Art. 31\%, "eximentes de responsabilidad penal»): por enfermedad mental o una deficiencia, estado de intoxicación, legítima defensa individual, o estado de necesidad coactivo («duress», se diferencia de la amenaza de muerte personal porque es un contexto de violencia superior que implica también amenaza de muerte).

190 Prosecutor vs. Blaskic. El general croata-bosnio T. Blaskic fue acusado de tolerar diversos crímenes cometidos por unidades militares bajo su mando.

191 Como bien planteó Röling, quien fuera profesor de Derecho Internacional y de Derecho Penal en la Universidad de Groningen (Holanda) y juez en el Tribunal Militar Internacional de Tokio, el problema del significado del alegato de órdenes superiores se ha convertido en uno de los más difíciles, desde que las órdenes nacionales pueden chocar con las normas internacionales. Cf., Röling, ibid., pp. 374-377. 
También están insertas las típicas causas para la exculpación: el error (Art. 32०, el error de hecho es eximente pues hace desaparecer el dolo o intención, mientras que el error de derecho no lo es porque la intención queda ${ }^{192}$ ) y la obediencia debida (Art. $33^{\circ}$, válido sólo para crímenes de guerra; en crímenes de genocidio y contra la humanidad se presume la ilicitud manifiesta de la orden).

\subsubsection{Jurisdiccion Ratione Loci}

En principio, y al igual que la CIJ, la CPI tendrá podrá llegar a tener jurisdicción mundial, aunque limitada inicialmente a los Estados que se conviertan en parte del Estatuto después de su entrada en vigor (Art. 110). Entrará en vigor cuando se deposite el sexagésimo instrumento de ratificación o adhesión, i.e., cuando sesenta Estados se conviertan en partes del estatuto de la CPI.

\subsubsection{Jurisdiccion Ratione Temporis}

La CPI tendrá jurisdicción respecto a crímenes cometidos sólo después de la entrada en vigor del Estatuto.

Para los Estados que se conviertan en partes del Estatuto después que éste entre en vigor, la Corte tendrá jurisdicción respecto a crímenes cometidos sólo después que el estatuto haya entrado en vigor para dicho Estado (Art. 11\%).

\subsection{Ejercicio de la Jurisdiccion de la CPI}

A la primera cuestión relevante sobre la CPI, vinculada con la jurisdicción, sucede la del ejercicio de la misma.

Para que la CPI pueda ejercer jurisdicción deberá cumplir con: las condiciones sobre las entidades facultadas para presentar un caso, precondiciones

192 Ambos cita un ejemplo de la diferencia de ambas clases de error. En el error de hecho, un soldado mata a un civil creyendo que era un soldado enemigo, le faltará el dolo o intención. En el error de derecho, si el soldado hubiera alegado que no era consciente que la muerte de civiles era punible, habría intervenido la regla ignorantia non nocet, pues este error deja intacto su dolo o intención puesto que él mató a los civiles conscientemente. Vid., Kai Ambos, «Sobre el fundamento jurídico de la Corte Penal Internacional: un análisis del Estatuto de Roman, Revista de Derecho Penaly Criminologia, 5 (2000), p. 146. 
que la Corte debe cumplir para ejercer su competencia, las causas de inadmisibilidad, y la intervención del Consejo de Seguridad.

\subsubsection{Sometimiento de un caso a la CPI}

La segunda cuestión fundamental se refiere a la legitimación para someter un caso a la CPI.

Concretamente, la Corte Penal Internacional podrá ejercer jurisdicción si cualquiera de las siguientes entidades presentan un caso ante la Corte: Estados parte, Consejo de Seguridad y el Fiscal.

(a). Los Estados parte:

Cualquier Estado parte puede denunciar una situación al fiscal para que investigue y así determine si individuos pueden ser acusados por haber cometido crímenes en dicha situación (Art. 13º, pár. a, y Art. 14º).

(b). El Consejo de Seguridad:

Conforme al Capítulo VII de la Carta de la ONU, puede remitir al fiscal una situación (Art. 13ㅇ, pár. b). Si este órgano inicia una investigación, puede solicitar a la CPI no iniciar una investigación o proceso por su parte ${ }^{193}$ (Art. $16^{\circ}$ del estatuto de la CPI y Capítulo VII de la Carta de la ONU).

(c). El Fiscal (procurador):

Puede iniciar investigación motu proprio (art. 15) y en base a sus propios informes ${ }^{194}$.

\subsubsection{Precondiciones para el ejercicio de la jurisdiccion..}

El tercer problema relevante se refiere a las precondiciones para que la CPI pueda ejercer jurisdicción en un caso concreto, pues la jurisdicción no será automática para los crímenes previstos.

193 Hasta por un período de 12 meses, renovables.

194 Si el Fiscal concluye que existe suficiente base para iniciar una investigación, puede presentar a la Cámara (Sala) de Cuestiones Preliminares una solicitud de autorización de una investigación. El rechazo de la Cámara a la autorización, no impedirá que el Fiscal presente otra solicitud basada en nueva evidencia (Art. 15º, pár. 4-5). 


\section{Figura 2: Ejercicio de la Jurisdicción de la CPI PROCESO PARA EL INICIO DEL EJERCICIO DE LA JURISDICCION POR LA CPI}

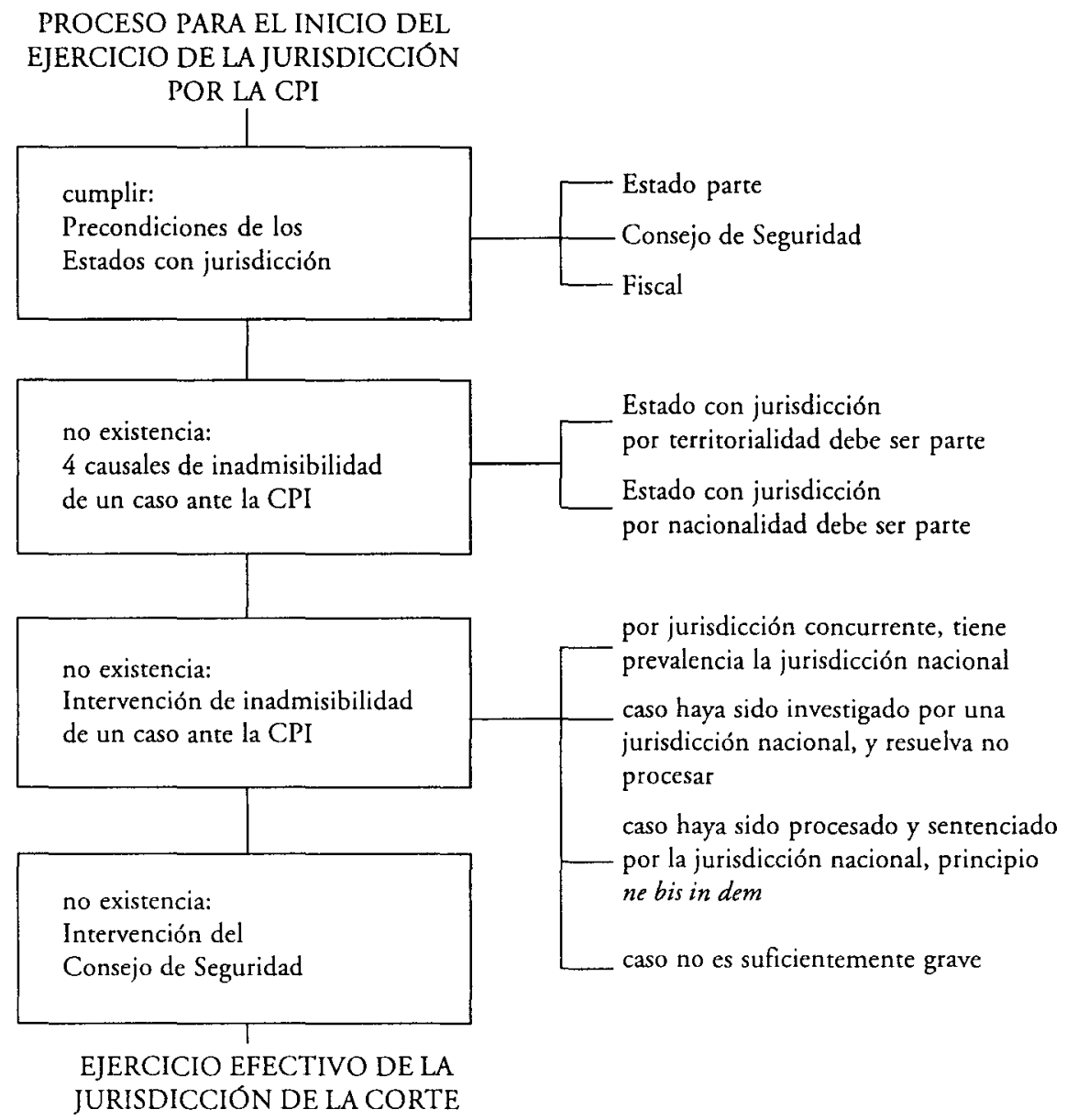

\section{EJERCICIO EFECTIVO DE LA JURISDICCION DE LA CORTE}

Nota: El ejercicio de la jurisdicción de la Corte deberá superar cuatro obstáculos antes de ejercerla efectivamente. 
La Corte podrá ejercer su jurisdicción si son partes del estatuto:

(a) el Estado en cuyo territorio se cometió el crimen, o

(b) el Estado del cual es nacional el acusado (Art. 12º pár. 2).

Asimismo, si dichos Estados no son partes del estatuto, éstos pueden aceptar la jurisdicción de la Corte para un caso particular mediante una declaración ad hoc depositada en la Secretaría (Art. 12º, pár. 3).

Si no sean podido sortear los obstáculos al ejercicio de la jurisdicción, queda el recurso al Consejo de Seguridad y que este órgano ponga en manos de la CPI un determinado caso (Art. 13º, pár. b).

Empero, si se ha podido sortear las precondiciones señaladas quedan por salvar las dificultades planteadas por las causas de inadmisibilidad.

\subsubsection{Inadmisibilidad de un caso ante la CPI}

Además, se manejan cuatro causas de inadmisibilidad de un caso ante la Corte:

(a) Cuando el caso esté siendo investigado o procesado por el Estado que tiene jurisdicción sobre el mismo (Art. 17º, pár. 1, inc. a); tiene jurisdicción primaria la jurisdicción nacional respecto a la CPI (principio de complementariedad).

(b) Cuando el caso haya sido investigado por el Estado que tiene jurisdicción y haya resuelto no procesar al individuo en cuestión (Art. 17\%, pár. 1, inc. b).

(c) Cuando el individuo haya sido procesado por la misma causa en otro tribunal (Art. 17º, pár. 1, inc. c; Art. 20º pár. 3). Validez del principio ne bis in idem.

(d) Cuando el caso no es de gravedad suficiente para justificar una intervención de la CPI (Art. 17º, pár. 1, inc. d).

Si no existen estos cuatro factores, entonces procede el ejercicio de la jurisdicción de la Corte.

\subsubsection{Intervencion del consejo de seguridad}

Una cuarta controversia respecto al ejercicio de la jurisdicción de la CPI es la intervención del Consejo de Seguridad de la ONU.

Si la denuncia procede del Consejo de Seguridad, en el marco del Capítulo VII de la Carta de la ONU (Art. $13^{\circ}$, inc. b del estatuto), la CPI podría así ejercer su competencia respecto de cualquiera de los crímenes 
previstos, con independencia de que haya habido aceptación previa por parte de los Estados que corresponda.

Sin embargo, se establece simultáneamente una limitación a la competencia de la Corte, en el sentido que no podrá iniciarse un procedimiento respecto a una situación de la que se esté ocupando el Consejo de Seguridad (Art. $16^{\circ}$ del estatuto) por tratarse, a tenor del Capítulo VII de la Carta, de una amenaza a la paz, un quebrantamiento de la paz o un acto de agresión.

\subsection{Derecho aplicable}

\subsubsection{Régimen legal aplicable: Jerarquía}

La CPI aplicará en orden de precedencia: primero, el Estatuto; segundo, los tratados y las reglas de Derecho Internacional (incluyendo los "principios establecidos del Derecho de los Conflictos Armados"); y tercero, los principios generales de Derecho (Art. 21ํ․ pár. 1). Finalmente, podrá aplicar su propia jurisprudencia (Art. $21^{\circ}$, pár. 2).

$\mathrm{Al}$ igual que los tribunales ad hoc, la CPI tendrá como fundamento jurídico complementario las «Reglas de Procedimiento y Prueba»; mas, a diferencia de los tribunales citados, los jueces no las promulgarán sino elaboradas por una Comisión Preparatoria (terminadas el 20 de junio del 2000) y aprobadas por la Asamblea de Estados partes.

\subsubsection{Principios generales de Derecho Penal}

\subsubsection{El Principio de Legalidad}

El principio de legalidad de los delitos y de las penas es fundamental en el Derecho Penal ${ }^{195}$. Este principio, que es el de la fidelidad a la ley y constituye la máxima garantía individual, consiste en la necesidad de la existencia de una ley previa al castigo ${ }^{196}$.

195 Para un análisis sobre la máxima nullum crimen, nulla poena sine lege, vid., Luis Jiménez de Asúa, La Leyy el Delito: Principios de Derecho Penal (Buenos Aires: Sudamericana, 1973), pp. 96-99. Asimismo, para un excelente estudio general sobre la teoría de la sanción penal, Luigi Ferrajoli, Derecho y Razón: Teoría del garantismo penal (Madrid: Trotta, 1995), pp. 353-457.

196 En el Derecho Procesal, el principio de legalidad constituye la observancia de las leyes de procedimiento, esto es el debido proceso. 
La mayor de las críticas contra los procesos de Nüremberg y de Tokio $^{197}$ señala el haber quebrantado el principio de legalidad debido a que los estatutos de ambos tribunales formalizaron delitos y penas a posteriori de los hechos cometidos en la Segunda Guerra Mundial.

Empero, para Oda, entre muchas opiniones de la doctrina, pese a esto tendría validez en aras del interés superior de la justicia:

"La controversia sobre si los juicios por crímenes de guerra, después de la Segunda Guerra Mundial constituyeron una aplicación ex post facto de supuestos principios de dudosa validez y una violación del principio nullum crimen sine lege, parece no tener gran importancia en vista del hecho de que el concepto de la responsabilidad directa del individuo, dentro del derecho internacional en el caso de ciertos crímenes, fue afirmado por el consentimiento mutuo de la comunidad de los Estados. Ciertos principios mantenidos por los juicios de Nüremberg y de Tokio fueron confirmados por la Asamblea General en $1946 .{ }^{198}$

Como puede observarse, la afirmación citada cobra validez por cuanto si bien existe controversia sobre la legalidad de los principios de Nüremberg y de Tokio ésta fue disipada al ser consagrados tales principios de forma unánime por la Asamblea General de la ONU mediante la Resolución 95 (I) de 1946. Esto es que el principio de legalidad debe ceder ante el principio superior de justicia sustantiva. En opinión de Pella, el respeto del principio de legalidad entonces hubiera asegurado una impunidad ${ }^{199}$.

Sin embargo, la doctrina se reafirma sobre la validez del principio de legalidad y nos recuerda que «debe ser respetado en el Derecho Penal Internacional, igual que en los Derechos nacionales, como exigencia de la seguridad jurídica, como garantía contra el abuso y la arbitrariedad ${ }^{200}$. Asimismo, este principio se encuentra consagrado como regla de Derecho Internacional en numerosas normas y tratados, como la Declaración Universal de Derechos Humanos (Art. 11º, pár. 2), la Convención Interna-

197 También, la mayoría de los juicios aliados después de 1945.

198 S. Oda, "El individuo en el derecho internacional», en: Max Sorensen (ed.), Manual de derecho internacional público (México: FCE, 1985), p. 494.

199 V. Pella, La guerre-crime et les criminels de guerra (Neuchatel: Baconniere, 1964), pp. 81 y 100 .

200 Vid., A. Gil Gil, Derecho penal intenacional (Madrid: Tecnos, 1999), p. 72. 
cional de Derechos Civiles y Políticos de 1966 (Art. 15), Convención Europea de Salvaguardia de los Derechos del Hombre de 1950, y Convención Americana de Derechos Humanos de 1969 (Art. 90). En consecuencia, los tribunales internacionales de la post-Guerra Fría recogieron este principio, y del mismo modo la CPI.

\subsubsection{El Principio de Legalidad en la CPI}

El principio de legalidad (referida por los juristas en el clásico aforismo latino de nullum crimen, nulla poena sine lege), que se divide en dos (el principio de la legalidad de los delitos, o de la garantía criminal, y el principio de la legalidad de las penas, o de la garantía penal) se halla consagrado en la Parte III «Los Principios Generales de Derecho Penal» del Estatuto de la Corte. La validez del principio de legalidad infiere a su vez la prohibición de la ley ex-post facto ${ }^{201}$.

\section{(A). Principio de legalidad de los delitos}

El principio de legalidad de los delitos, o de garantía criminal ( $n u l l u m$ crimen sine lege), está establecido firmemente (Art. 22\%, un individuo sólo puede ser responsable por actos considerados como crímenes de acuerdo a este Estatuto).

Esto significa que los dos principios angulares de del de legalidad de los delitos se hallan insertos: el principio de taxatividad, que requiere la máxima certeza en la definición de los delitos (Art. 22, pár. 1); y el principio de interpretación estricta de la ley penal, que prohibe la interpretación extensiva o por analogía en contra del acusado (Art. 22\%, pár. 2 ).

\section{(B). Principio de legalidad de las penas}

El principio de legalidad de las penas, o de garantía penal (nulla poena sine lege) está consagrado (Art. 23으. un individuo sólo puede ser castigado penalmente conforme a este estatuto).

\section{(C). Principio de irretroactividad de la ley penal}

Si bien en sentido estricto el principio de no aplicación retroactiva de la ley penal al acusado, o de irretroactividad de la ley penal (irretroactividad ratione personae) y que permite al acusado la retroactividad de la ley favo- 
rable en caso de modificación, no forma parte del principio de legalidad, es una práctica común su inclusión.

El principio de irretroactividad de la ley penal ratione personae está también afirmado en el estatuto de la CPI (i.e., un individuo no puede ser responsable penalmente por actos realizados previamente a la vigencia del Estatuto, Art. 24). En virtud de esta premisa, dirigentes acusados de violar los derechos humanos como Pinochet, Milosevic, Saddam Hussein o Idi Amin Dada no podrían ser juzgados por este tribunal.

\subsubsection{Otros principios de Derecho Penal}

Por su parte, un principio procesal básico que está incluido en el estatuto es el principio ne bis in idem (aunque no en la Parte III, sino en la II) y según el cual nadie podrá ser procesado ante la CPI respecto a la conducta por la cual tal individuo ya antes había sido juzgado y sentenciado (principio de res iudicata), sea condenado o absuelto por esta Corte $\mathrm{u}$ otro tribunal (Art. $20^{\circ}$ ). El principio procesal del debido proceso está también inserto en el estatuto (arts. $63^{\circ}-67^{\circ}$ ).

El Derecho y normas aplicables por la Corte, enumerados jerárquicamente, se hallan en la Parte II.

Hay otros principios insertos en esta Parte III, pero que en realidad constituyen principios y reglas de responsabilidad penal individual, los cuales son: el de responsabilidad directa individual, el de irrelevancia de la inmunidad soberana de Estados, el de responsabilidad de mando por crimen por omisión, y el de irrelevancia de la obediencia debida a órdenes superiores. Todos comprendidos dentro de la jurisdicción ratione materiae.

Un principio fundamental del Derecho Penal Internacional es el de la imprescriptibilidad de los crímenes internacionales (Art. 29\%), según el cual los crímenes objeto de la jurisdicción de la Corte (los crímenes internacionales) que cometan los acusados jamás prescribirán ${ }^{202}$.

\subsubsection{Penas aplicables}

Las penas pueden establecer un máximo de treinta años de prisión, aunque para casos excepcionales se puede aplicar la cadena perpetua (debido a la extrema gravedad del crimen, Art. $77^{\circ}$, pár. 1). Al igual que los

202 Crímenes que sean cometidos después del momento en que entre en vigor el estatuto de la CPI. 
tribunales ad hoc creados por el Consejo de Seguridad, no se contempla la pena de muerte.

Asimismo, se prevé otras sanciones como multas y decomiso de bienes (Art. $7^{\circ}$, pár. 2).

\subsection{Organizacion de la corte}

La CPI está constituida por cuatro órganos: la Presidencia, las Secciones Judiciales, la Fiscalía y la Secretaría (Art. 34\%).

\subsubsection{La presidencia de la CPI}

La Presidencia (Art. 38०, "The Presidency» en la versión en inglés del estatuto) estará integrada por un presidente y dos vicepresidentes. Su función será encargarse de la correcta administración de la Corte. Sus integrantes deberán ser elegidos entre la mayoría de magistrados de la Corte.

Los magistrados («judges») que constituyan la CPI serán elegidos en un total de dieciocho por la Asamblea de los Estados partes (Art. 36०). Los magistrados deberán cumplir sus funciones a dedicación exclusiva, $y$ no podrán haber dos de la misma nacionalidad (arts. $35^{\circ}-36^{\circ}$ ).

\subsubsection{Secciones de la CPI y sus salas}

Las Secciones ( DDivisions») constituyen la estructura en que la Corte se organizará (Art. 39º, pár. 1). Serán tres: la Sección de Apelaciones («Appeals Division», integrada por el Presidente y cuatro magistrados), la Sección de Primera Instancia ("Trial Division", al menos seis magistrados), y la Sección de Cuestiones Preliminares («Pre-Trial Division», al menos seis magistrados).

Las funciones judiciales de la Corte serán realizadas en cada sección por las Salas ("Chambers», Art. 39º, pár. 2).

Todos los magistrados de la Sección de Apelaciones integrarán la Sala de Apelaciones ("Appeals Chamber»), la instancia judicial máxima.

Tres magistrados de la Sección de Primera Instancia integrarán la Sala de Primera Instancia ("Trial Chamber»). Las decisiones de esta primera instancia podían ser apeladas por el fiscal o la persona condenada. El proceso deberá ser en presencia del acusado. 
Tres magistrados de la Sección de Cuestiones Preliminares integrarán la Sala de Cuestiones Preliminares («Pre-Trial Chamber»). Esta Cámara o Sala puede emitir una orden de arresto, se espera que el Estado que tiene en custodia al acusado coopere con la Corte. Puede en circunstancias excepcionales llevar a cabo audiencias en ausencia de la persona acusada.

\subsubsection{La Fiscalía}

La Fiscalía ( "The Office of the Prosecuton, Art. 42\%) actuará en forma independiente. Estará dirigida por el Fiscal ( Prosecutor») y contará con la ayuda de uno o más fiscales adjuntos ( (Deputy Prosecutors»). ${ }^{203}$

\subsubsection{La secretaría}

La Secretaría ("The Registry", Art. 43) estará encabezada por el Secretario ("the Registrar»), principal funcionario administrativo de la CPI, y quedará bajo la autoridad del Presidente de la Corte. El Secretario deberá ser elegido por los magistrados.

\subsection{Investigacion y proceso}

\subsubsection{Investigación y acusación}

El estatuto no impedirá la jurisdicción de la CPI sobre la conducta criminal de individuos aunque haya sido cubierta por amnistías o comisiones de la verdad (cuya finalidad sea la de establecer la impunidad de estos crímenes internacionales). Mas, permite al fiscal no proceder con una investigación si no sirve al interés de la justicia (Art. 53ㅇ).

La Sala de Cuestiones Preliminares puede emitir una orden de arresto en base a la solicitud del fiscal (si se cumple que hay bases razonables para creer que la persona ha cometido un crimen objeto de la jurisdicción de la Corte (Art. 58 $)$. Se espera que el Estado que tiene la custodia cumpla con tal orden (Art. 59\%). 
La Sala de Cuestiones Preliminares deberá efectuar audiencias para confirmar los cargos en presencia de la persona acusada. Empero, en circunstancias excepcionales, esta Sala puede efectuar una audiencia en ausencia de la persona acusada (Art. 61\%), facultad que también posee el Tribunal de la Antigua Yugoslavia en virtud de la Regla 61.

\subsubsection{El proceso}

El proceso deberá realizarse en presencia del acusado (Art. 63), rectificando la labor de Nüremberg y ratificando la conducta de los tribunales ad hoc.

El importantísimo principio procesal del debido proceso está asegurado en el estatuto (arts. $63^{\circ}-67^{\circ}$ ), y por el cual el acusado disfruta, inter alia: del derecho de tener un juicio público y justo conducido imparcial y rápidamente; siendo inmediatamente informado de los cargos en el idioma que comprenda y hable; tenga tiempo adecuado y facilidades para preparar su defensa y examinar a los testigos contra él antes o durante el juicio; que tenga la libre asistencia de un intérprete y traducciones; y no ser obligado a testificar o confesarse culpable.

Sobre información que afecte la seguridad nacional de un Estado, ésta deberá revelarse a la Corte bajo un acuerdo que permita la inclusión de procedimientos in camera o ex parte ("a puerta cerrada", Art. $72^{\circ}$, pár. 5 , inc. d, del estatuto), o cualquier otra medida protectora permitida. ${ }^{204}$

En cuanto a la reparación a las víctimas, el estatuto requiere que la Corte establezca principios relativos a las reparaciones a las víctimas, incluyendo restitución, compensación y rehabilitación (Art. 75\%).

\subsubsection{Penas}

Las penas contempladas en el estatuto no incluyen la pena de muerte. Este tema fue muy debatido en la Conferencia de Roma, y la fórmula de compromiso fue que no se incluiría en el estatuto la pena capital, pero el Presidente de la Conferencia leyó una declaración, con apoyo de los Esta-

204 La protección de los intereses de seguridad nacional se vio ilustrado en el caso Blaskic ante el Tribunal de la Antigua Yugoslavia, cuando Croacia solicitó la revisión de la decisión de la primera instancia de julio de 1997 que obligaba a la entrega de evidencia que afectaba la seguridad croata. En relación a dicha protección, vid., Arbour, Eser, Ambos y Sanders, op. cit., p. 108. 
dos que sí defienden la pena de muerte (e.g., los Estados árabes y los Estados de Asia Sudoriental), dejando en claro que no existía consenso sobre la inclusión o exclusión de dicha pena.

La declaración señalaba que en virtud del principio de complementariedad, la jurisdicción primaria sería la nacional, ergo cada Estado decidiría en cuanto a la investigación, procesamiento y castigo de individuos según su sistema jurídico, y serían libres de aplicar las penas conforme a sus sistemas jurídicos.

\subsubsection{Apelación}

El estatuto permite que la sentencia de la Sala de Primera Instancia sea apelada por el fiscal o el individuo condenado.

Otras decisiones que pueden ser apeladas incluyen aquellas relacionadas con la jurisdicción, ejercicio de la jurisdicción, la concesión de libertad de la persona acusada, la conducta justa del proceso, y las facultades de la Sala de Cuestiones Preliminares (Art. 810).

\section{Conclusiones}

Un elemento central del Derecho Penal Internacional lo constituye la determinación de los crímenes internacionales, en sentido estricto y en sentido amplio, lo que conduce a la responsabilidad penal del individuo. Esta clase de responsabilidad puede coexistir con la responsabilidad del Estado. La aplicación de las penas, siempre ha sido, por regla, misión de las jurisdicciones nacionales; por excepción lo ha sido de los tribunales internacionales.

La formulación y creación de tribunales penales internacionales después de la Primera Guerra Mundial, de la Segunda Guerra Mundial y de la Guerra Fría, a lo largo del siglo XX, constituyeron una contribución decisiva en el desarrollo del Derecho Penal Internacional.

Finalmente, un aporte significativo en la codificación de esta disciplina jurídica y en la creación de su brazo principal, lo representa el surgimiento de la Corte Penal Internacional. Dicha Corte constituye una codificación provisional y moderna de esta rama del Derecho Internacional.

Como puede inferirse del Estatuto, la CPI puede acabar configurándose sólo como instancia excepciones, para casos y crímenes muy concretos, en supuestos en que las jurisdicciones nacionales no actúen de forma 
eficaz; un sistema que sólo puede descansar en la definición de un sistema de valores universalmente compartido y que tales valores deben primar sobre cualquier otra cosa.

Pese a todas las limitaciones inherentes, su creación representa un avance notable con respecto al pasado del género humano y conforme evolucione la comunidad internacional, esta institución responderá a las esperanzas del mundo.

\section{Anexo 1 \\ Los Estados Signatarios y Ratificantes del Estatuto de la CPI hasta octubre del 2000}

El estatuto fue aprobado en la Conferencia de Roma del 17 de julio de 1998 por 120 Estados $^{205}$. Conforme al Art. $125^{\circ}$ del estatuto de la CPI, el estatuto estuvo abierto para la suscripción de los Estados hasta el 31 de diciembre de 2000 .

El estatuto entrará en vigor cuando sesenta Estados depositen sus instrumentos de ratificación o adhesión. El primer Estado que ratificó el estatuto fue San Marino (el 13 de mayo de 1999). Hasta octubre del 2000, eran 114 los Estados signatarios y 21 los ratificantes $\left(^{*}\right)$

1. Albania 18 de julio de 1998

2. Andorra 18 de julio de 1998

3. Angola 7 de octubre de 1998

4. Antigua y Barbuda 23 de octubre de 1998

5. Argentina 8 de enero de 1999

6. Armenia 1 de octubre de 1999

7. Australia 9 de diciembre de 1998

8. Austria 7 de octubre de 1998

9. Bangladesh 16 de setiembre de 1999

10. Barbados 8 de setiembre del 2000

11. Bélgica 10 de setiembre de 1998 (*28 jun 2000)

205 Fue aprobado el estatuto por votación mayoritaria 121 Estados a favor, 7 en contra y 21 abstenciones. Debido a que la votación se hizo sólo por conteo de la cantidad y no nominalmente, no se conoce exacta y oficialmente cómo votó cada país. Empero, se sabe que Estados Unidos, Israel, India y China Popular votaron en contra; y se presume que Libia, Irak e Irán votaron también en contra. 
12. Belice 5 de abril del $2000(* 5$ abr 2000)

13. Benin 24 de setiembre de 1999

14. Bolivia 17 de julio de 1998

15. Bosnia-Herzegovina 17 de julio del 2000

16. Botswana 8 de setiembre del $2000\left({ }^{*} 8\right.$ set 2000$)$

17. Brasil 7 de febrero del 2000

18. Bulgaria 11 de febrero de 1999

19. Burkina Faso 30 de noviembre de 1998

20. Burundi 13 de enero de 1999

21. Camboya 23 de octubre del 2000

22. Camerún 17 de julio de 1998

23. Canadá 18 de diciembre de 1998 (*7 jul 2000)

24. Rep. Centroafricana 7 de diciembre de 1999

25. Chad 20 de octubre de 1999

26. Chile 11 de diciembre de 1998

27. Colombia 10 de diciembre de 1998

28. Islas Comoras 22 de setiembre del 2000

29. Congo (Brazzaville) 17 de julio de 1998

30. Costa Rica 7 de octubre de 1998

31. Cote d'Ivoire 30 de noviembre de 1998

32. Croacia 12 de octubre de 1998

33. Chipre 15 de octubre de 1998

34. República Checa 13 de abril de 1999

35. Rep. Dem. del Congo 8 de setiembre del 2000

36. Dinamarca 25 de setiembre de 1998

37. Djibuti 7 de octubre de 1998

38. Rep. Dominicana 8 de setiembre del 2000

39. Ecuador 7 de octubre de 1998

40. Eritrea 7 de octubre de 1998

41. Estonia 27 de diciembre de 1999

42. Fiji 29 de noviembre de 1999 (*29 nov 1999)

43. Finlandia 7 de octubre de 1998

44. Francia 18 de julio de 1998

45. Gabón 22 de diciembre de 1998 (* 20 set 2000)

46. Gambia 7 de diciembre de 1998

47. Georgia 18 de julio de 1998

48. Alemania 10 de diciembre de 1998

49. Ghana 18 de julio de 1998 (* 20 dic 1999) 
50. Grecia 18 de julio de 1998

51. Guinea 7 de setiembre del 2000

52. Guinea-Bissau 12 de setiembre del 2000

53. Haiti 26 de febrero de 1999

54. Honduras 7 de octubre de 1998

55. Hungría 15 de enero de 1999

56. Islandia 26 de agosto de 1998 (* 25 may 2000)

57. Irlanda 7 de octubre de 1998

58. Italia 18 de julio de 1998 (*26 jul 1999)

59. Jamaica 8 de setiembre del 2000

60. Jordania 7 de octubre de 1998

61. Kenia 11 de agosto de 1999

62. Kuwait 8 de setiembre del 2000

63. Kirguistán 8 de diciembre de 1998

64. Letonia 22 de abril de 1999

65. Lesotho 30 de noviembre de 1998 (* 6 set 2000)

66. Liberia 17 de julio de 1998

67. Liechtenstein 18 de julio de 1998

68. Lituania 10 de diciembre de 1998

69. Luxemburgo 13 de octubre de $1998\left({ }^{*} 8\right.$ set 2000$)$

70. Madagascar 18 de julio de 1998

71. Malawi 2 de marzo de 1999

72. Malí 17 de julio de 1998 (*16 ago 2000)

73. Malta 17 de julio de 1998

74. Islas Marshall 6 de setiembre del 2000

75. Mauricio 11 de noviembre de 1998

76. México 7 de setiembre del 2000

77. Mónaco 18 de julio de 1998

78. Marruecos 8 de setiembre del 2000

79. Namibia 27 de octubre de 1998

80. Holanda 18 de julio de 1998

81. Nueva Zelandia 7 de octubre de $1998\left({ }^{*} 7\right.$ set 2000)

82. Níger 17 de julio de 1998

83. Nigeria 1 de junio del 2000

84. Noruega 28 de agosto de 1998 (* 16 feb 2000)

85. Panamá 18 de julio de 1998

86. Paraguay 7 de octubre de 1998

87 Polonia 9 de abril de 1999 
88. Portugal 7 de octubre de 1998

89. Corea del Sur 8 de marzo del 2000

90. Moldova 8 de setiembre del 2000

91. Rumania 7 de julio de 1999

92. Rusia 13 de setiembre del 2000

93. Santa Lucía 27 de agosto de 1999

94. Samoa 17 de julio de 1998

95. San Marino 18 de julio de 1998 (* 13 may 1999)

96. Senegal 18 de julio de 1998 (* 2 feb 1999)

97. Sierra Leona 17 de octubre de 1998 (* 15 set 2000)

98. Eslovaquia 23 de diciembre de 1998

99. Eslovenia 7 de octubre de 1998

100. Islas Salómon 3 de diciembre de 1998

101. Sudáfrica 17 de julio de 1998

102. Sudán 8 de setiembre del 2000

103. España 18 de julio de 1998

104. Suecia 7 de octubre de 1998

105. Suiza 18 de julio de 1998

106. Tayikistán 30 de noviembre de 1998 ( ${ }^{*} 5$ may 2000)

107. Tailandia 2 de octubre del 2000

108. Trinidad y Tobago 23 de marzo de $1999\left({ }^{*} 6\right.$ abr 1999)

109. Uganda 17 de marzo de 1999

110. Ucrania 20 de enero del 2000

111. Macedonia 7 de octubre de 1998

112. Reino Unido 30 de noviembre de 1998

113. Venezuela 14 de octubre de 1998 (*7 jun 2000)

114. Zambia 17 de julio de 1998

115. Zimbabwe 17 de julio de 1998 


\section{Anexo 2 \\ Clausula Martens}

La IV Convención de La Haya relativa a las leyes y costumbres de la guerra terrestre (18 de octubre de 1907) incluye un preámbulo y 9 artículos, más un anexo (el Reglamento de las leyes y costumbres de la guerra terrestre). En la segunda parte del preámbulo está insertada la llamada Cláusula Martens (elaborada por vez primera en 1899). A continuación, consignamos el texto de la cláusula:

«Mientras, llega la redacción de un código más completo de las leyes de la guerra, las altas partes contratantes consideran oportuno hacer constar que, las altas partes contratantes consideran oportuno hacer constar que, en los casos no comprendidos en las disposiciones reglamentarias por ellas adoptadas, las poblaciones y los beligerantes quedarán bajo la salvaguardia y bajo el imperio de los principios del Derecho Internacional, resultantes de las costumbres recibidas entre naciones civilizadas, de las leyes de la humanidad y de los imperativos de la conciencia pública." 


\section{Anexo 3}

\section{Procesos Ante El Tribunal Para La Antigua Yugoslavia}

\section{Tabla 2:}

Situación de los procesos ante el Tribunal Internacional Penal para la Antigua Yugoslavia (octubre del 2000)

\begin{tabular}{|c|c|c|c|}
\hline $\begin{array}{l}\text { Acusación } \\
\text { (casos) }\end{array}$ & $\begin{array}{l}\text { Nombres de los } \\
\text { acusados }\end{array}$ & $\begin{array}{l}\text { Tomados bajo } \\
\text { custodia del } \\
\text { Tribunal }\end{array}$ & Situación del Proceso \\
\hline Tadic et al & $\begin{array}{l}\text { 1. Dusko Tadic } \\
\text { (A) }\end{array}$ & Abril de 1995 & $\begin{array}{l}\text { Condenado en mayo de } 1997 \text { y } \\
\text { sentenciado (jul. 1997) a } 20 \text { años, } \\
\text { apelación (ene. 2000) confirma la } \\
\text { sentencia }\end{array}$ \\
\hline \multirow{4}{*}{$\begin{array}{l}\text { Delalic et } \\
\text { al. ("Campo } \\
\text { Celebici») }\end{array}$} & $\begin{array}{l}\text { 2. Hazim Delic } \\
\text { (A) }\end{array}$ & Junio de 1996 & $\begin{array}{l}\text { Condenado a } 20 \text { años nov. } 1998 . \\
\text { Apelación. }\end{array}$ \\
\hline & $\begin{array}{l}\text { 3. Esad Landzo } \\
\text { (A) }\end{array}$ & Junio de 1996 & $\begin{array}{l}\text { Condenado/sentenciado a } 15 \text { años } \\
\text { nov. } 1998 \text {. Apelación. }\end{array}$ \\
\hline & $\begin{array}{l}\text { 4. Zdravko } \\
\text { Mucic (A) }\end{array}$ & Abril de 1996 & $\begin{array}{l}\text { Condenado/sentenciado a } 7 \text { años } \\
\text { nov. } 1998 \text {. Apelación }\end{array}$ \\
\hline & Zejnil Delalic (A) & Mayo de 1996 & Absuelto/liberado en nov. 1998 \\
\hline Blaskic & $\begin{array}{l}\text { 5. Tihomir } \\
\text { Blaskic (E) }\end{array}$ & Abril de 1996 & $\begin{array}{l}\text { Inicio del proceso jun. } 1997, \\
\text { condenado (ene. 2000) a } 45 \text { años de } \\
\text { prisión. Apelación pendiente. }\end{array}$ \\
\hline Kordic et al. & $\begin{array}{l}\text { 6. Zlatko } \\
\text { Aleksovski (A) }\end{array}$ & Abril de 1997 & $\begin{array}{l}\text { Condenado (mar. 2000) a } 7 \text { años } \\
\text { (Aleksovski de prisión que cumple } \\
\text { en Finlandia. }\end{array}$ \\
\hline Kordic et al. & $\begin{array}{l}\text { 7. Mario } \\
\text { Cerkez (E) } \\
\text { 8. Dario } \\
\text { Kordic (E) } \\
\text { Pero Skopljak } \\
\text { Iuan Santic }\end{array}$ & $\begin{array}{l}\text { Oct. de } 1997 \\
\text { Oct. de } 1997 \\
\text { Octubre de } 1997 \\
\text { Octubre de } 1997\end{array}$ & $\begin{array}{l}\text { Inicio de proceso abr. } 1999 . \\
\text { Inicio de proceso abr. } 1999 . \\
\text { Liberado en diciembre de } 1997 \\
\text { Liberado en diciembre de } 1997\end{array}$ \\
\hline \multirow[t]{3}{*}{$\begin{array}{l}\text { Kupreskic } \\
\text { etal. }\end{array}$} & $\begin{array}{l}\text { 9. Drago } \\
\text { Josipovic (E) }\end{array}$ & Oct. 1997 & $\begin{array}{l}\text { Condenado a } 15 \text { años (ene. 2000). } \\
\text { Apelación. }\end{array}$ \\
\hline & $\begin{array}{l}\text { 10. Mirjan } \\
\text { Kupreskic (E) }\end{array}$ & $\begin{array}{l}\text { Octubre de } \\
1997\end{array}$ & $\begin{array}{l}\text { Condenado a } 8 \text { años de prisión. Ape- } \\
\text { lación. }\end{array}$ \\
\hline & $\begin{array}{l}\text { 11. Vlatko } \\
\text { Kupreskic } \\
\text { (OTAN) }\end{array}$ & Dic. 1997 & $\begin{array}{l}\text { Condenado (ene. 2000) a } 6 \text { años } 12 . \\
\text { Zoran Kupreskic (E) Octubre de } \\
1997 \text { Condenado (ene. 2000) a } 10 \\
\text { años. Apelación. }\end{array}$ \\
\hline
\end{tabular}




\begin{tabular}{|c|c|c|c|}
\hline \multirow[t]{4}{*}{$\begin{array}{c}\text { Acusación } \\
\text { (casos) }\end{array}$} & $\begin{array}{c}\text { Nombres de los } \\
\text { acusados }\end{array}$ & $\begin{array}{l}\text { Tomados bajo } \\
\text { custodia del } \\
\text { Tribunal }\end{array}$ & Situación del Proceso \\
\hline & Dragan Papic & Oct. de 1997 & Absuelto y liberado en ene. 2000 \\
\hline & $\begin{array}{l}\text { 13. Vladimir } \\
\text { Santic (E) }\end{array}$ & Oct. de 1997 & $\begin{array}{l}\text { Condenado a } 25 \text { años de prisión. Ape- } \\
\text { lación. }\end{array}$ \\
\hline & Marinko Katava & Oct. de 1997 & Liberado en dic. de 1997 \\
\hline Furundzija & $\begin{array}{l}\text { 14. Anto } \\
\text { Furundzija } \\
\text { (OTAN) }\end{array}$ & Dic. 1997 & $\begin{array}{l}\text { Condenado/sentenciado a } 10 \text { años en } \\
\text { diciembre de } 1998 \text { que cumple en } \\
\text { Finlandia. }\end{array}$ \\
\hline $\begin{array}{l}\text { Jelisic } \\
\text { («Brckko") }\end{array}$ & $\begin{array}{l}\text { 15. Goran Jelisic } \\
\text { (OTAN) }\end{array}$ & Enero de 1998 & $\begin{array}{l}\text { Sentenciado (dic. 1999) a } 40 \text { años de } \\
\text { prisión. Apelación. }\end{array}$ \\
\hline \multirow{4}{*}{$\begin{array}{l}\text { Simic et al. } \\
\text { («Bosanski } \\
\text { Samac») }\end{array}$} & & & \\
\hline & $\begin{array}{l}\text { 17. Miroslav } \\
\text { Tadic (E) }\end{array}$ & Feb. de 1998 & Liberación provisional abr 2000 \\
\hline & 18. Simo Zaric (E) & Feb. de 1998 & Liberación prov. abr 2000 \\
\hline & $\begin{array}{l}\text { 19. Stevan } \\
\text { Todorovic } \\
\text { (OTAN) }\end{array}$ & Set. 1998 & Etapa preliminar. \\
\hline $\begin{array}{l}\text { Kunarac } \& \\
\text { Kovac ("Foča») }\end{array}$ & $\begin{array}{l}\text { 20. Dragoljub } \\
\text { Kunarac (E) }\end{array}$ & Mar. 1998 & Inicio de proceso mar. 2000 \\
\hline \multirow{5}{*}{$\begin{array}{l}\text { Campos } \\
\text { Omarska } \\
\text { y Keraterm } \\
\text { ( (Kvocka et } \\
\text { al.») }\end{array}$} & $\begin{array}{l}\text { 21. Miroslav } \\
\text { Kvocka (OTAN) }\end{array}$ & & \\
\hline & $\begin{array}{l}\text { 22. Mladen } \\
\text { Radic (OTAN) }\end{array}$ & Abr. 1998 & Inicio de proceso feb. 2000 \\
\hline & 23. Zoran Zigic (E) & Abril de 1998 & Inicio de proceso feb. 2000 \\
\hline & $\begin{array}{l}\text { 24. Milojica Kos } \\
\text { (OTAN) }\end{array}$ & Mayo de 1998 & Inicio del proceso feb. 2000 \\
\hline & $\begin{array}{l}\text { 25. Dragoljub } \\
\text { Prcac (OTAN) }\end{array}$ & Mar. 2000 & Inicio del proceso may. 2000 \\
\hline $\begin{array}{l}\text { Krnojelac } \\
\text { («Foča») }\end{array}$ & $\begin{array}{l}\text { 26. Milorad } \\
\text { Krnojelac } \\
\text { (OTAN) }\end{array}$ & Jun. 1998 & Etapa preliminar. \\
\hline Krstic & $\begin{array}{l}27 . \text { Radislav } \\
\text { Krstic (OTAN) }\end{array}$ & Dic. 1998 & Inicio del proceso feb. 2000 \\
\hline Erdemovic & $\begin{array}{l}\text { 28. Drazen } \\
\text { Erdemovic (A) }\end{array}$ & Mar. 1996 & $\begin{array}{l}\text { Confesó culpabilidad y sentenciado a } \\
5 \text { años de prisión en marzo de } 1998, \\
\text { que cumple en Noruega. }\end{array}$ \\
\hline
\end{tabular}




\begin{tabular}{|c|c|c|c|}
\hline $\begin{array}{l}\text { Acusación } \\
\text { (casos) }\end{array}$ & $\begin{array}{c}\text { Nombres de los } \\
\text { acusados }\end{array}$ & $\begin{array}{c}\text { Tomados bajo } \\
\text { custodia del } \\
\text { Tribunal } \\
\end{array}$ & Situación del Proceso \\
\hline $\begin{array}{l}\text { Naletilic \& } \\
\text { Martinovic }\end{array}$ & $\begin{array}{l}\text { 29. Vinko } \\
\text { Martinovic(A) } \\
\text { 30. Mladen } \\
\text { Naletilic (A) }\end{array}$ & $\begin{array}{l}\text { ago. } 1999 \\
\text { mar. } 2000\end{array}$ & $\begin{array}{l}\text { Etapa preliminar. } \\
\text { Etapa preliminar. }\end{array}$ \\
\hline $\begin{array}{l}\text { Brdjanin \& } \\
\text { Talic }\end{array}$ & $\begin{array}{l}\text { 31. Momir } \\
\text { Talic (A) } \\
\text { 32. Radoslav } \\
\text { Brdjanin (OTAN) }\end{array}$ & $\begin{array}{l}\text { ago. } 1999 \\
\text { jul. } 1999\end{array}$ & $\begin{array}{l}\text { Etapa preliminar. } \\
\text { Etapa preliminar. }\end{array}$ \\
\hline $\begin{array}{l}\text { Sikirica et al. } \\
\text { ("Campo } \\
\text { Keraterm") }\end{array}$ & $\begin{array}{l}\text { 33. Dragan } \\
\text { Kolundzija } \\
\text { (OTAN) } \\
\text { 34. Damir Dosen } \\
\text { (OTAN) } \\
\text { 35. Dusko } \\
\text { Sikirica (OTAN) }\end{array}$ & $\begin{array}{l}\text { jun. } 1999 \\
\text { oct. } 1999 \\
\text { jun. } 2000\end{array}$ & $\begin{array}{l}\text { Etapa preliminar. } \\
\text { Etapa preliminar. } \\
\text { Etapa preliminar. }\end{array}$ \\
\hline Galic & $\begin{array}{l}\text { 36. Stanislav } \\
\text { Galic (OTAN) }\end{array}$ & dic. 1999 & Etapa preliminar. \\
\hline $\begin{array}{l}\text { Kunarac, Kovac } \\
\& \text { Vukovic }\end{array}$ & $\begin{array}{l}\text { 37. Zoran } \\
\text { Vukovic (OTAN) } \\
\text { 38. Radomir } \\
\text { Kovac (OTAN) }\end{array}$ & $\begin{array}{l}\text { dic. } 1999 \\
\text { ago. } 1999\end{array}$ & $\begin{array}{l}\text { Inicio de proceso mar. } 2000 . \\
\text { Inicio del proceso mar. } 2000 .\end{array}$ \\
\hline Vasiljevic & $\begin{array}{l}\text { 39. Mitar } \\
\text { Vasiljevic } \\
\text { (OTAN) }\end{array}$ & ene. 2000 & Etapa preliminar. \\
\hline Krajisnik & $\begin{array}{l}\text { 40. Momcilo } \\
\text { Krajisnik } \\
\text { (OTAN) }\end{array}$ & abr. 2000 & Etapa preliminar. \\
\hline OTROS & $\begin{array}{l}\text { Stipo Alilovic } \\
\text { Djorde Dukic } \\
\text { Simo Drljaca } \\
\text { Slavko } \\
\text { Dokmanovic } \\
\text { Milan Kovacevic } \\
\text { Slobodan } \\
\text { Miljkovic }\end{array}$ & $\begin{array}{l}\text { Murió en } 1995 \\
\text { Murió en } 1996 \\
\text { Murió en } 1997 \\
\text { Se suicidó en } \\
1998 \\
\text { Murió en } 1998 \\
\text { Murió en } 1998\end{array}$ & Se abandonaron las acusaciones \\
\hline
\end{tabular}

Fuente: International Criminal Tribunal for the Former Yugoslavia, http:/www.un.org/icty/

Nota: Algunos Estados han arrestado a los acusados en su territorio y asi fueron transferidos al Tribunal. Presiones sobre Croacia ayudaron a promover el arresto o la entrega voluntaria de acusados. Las detenciones forzadas de la OTAN en Bosnia (que habían culminado en al gunos casos con la muerte de los acusados) estimuló mayores entregas voluntarias de acusados pues temían artestos forzados. Aquí no se incluyen a criminales de guerra acusados aún no detenidos como Milosevic, Mrksic, Martic, Karadzic y Mladic. Tampoco se incluyen a acusados muertos durante las operaciones de decención forzada de la OTAN.

Clave: (A) arrestado por autoridades de un Estado y transferidos al Tribunal, (E) se entregó voluntariamente, (OTAN) detenidos por fuerzas de la OTAN. 